\title{
The geologic structure of the Akkermanovka fragment of the Khabarny Massif ophiolite association (South Ural)
}

\author{
A. A. Razumovskiy \\ Geological Institute, Russian Academy of Sciences, Moscow, Russia
}

Received 25 May 2006; revised 18 June 2006; accepted 2 August 2006; published 20 August 2006.

[1] Using the results of geological mapping, including the petrostructural and petrochemical data, available, as well as the results of the previous researchers, a composite characteristic is offered for the geologic structure of the Akkermanovka fragment of the ophiolite sequence of the Khabarny Massif (South Ural). The position of this fragment in the enclosing structure is shown, and the structure of its paleooceanic crust rocks is discussed. The plutonic rock complex is distinguished by the unified layering from the olivine pyroxenitewehrlite to olivine gabbro - gabbronorite. The linear banding folds show the NW strike and predominant gentle and intermediate dip angles of their limbs. The general bedding is violated by late gabbronorite and pyroxenite veins. The composition of the gabbro"pegmatites" (the latest rocks) correlates with the composition of the enclosing rocks. The root zone of the dike complex is almost completely absent. The screen distribution shows the discrete distribution of the layered rock complex in the mantle tectonites. The sheeted dike complex is characterized by acid magmatism, expressed in the presence of veins and stocks of different sizes and also by the granitoid material filling the matrix of the magmatic breccias. These rock complexes seem to have been formed under the conditions of a suprasubduction marginal-sea basin. Spreading took place under the conditions of a deficient magma budget and was marked by the existence of numerous totally or partly synchronous extension axes, both differing in the direction of the spreading block vector. The upper age limit of this process is assumed to be Famennian (366 \pm 2 million years). At the post-oceanic stage of their development the rock complexes discussed were included into the structure of the accretion prism and thrust over the margin of the East European Continent (Late Devonian to Early Carboniferous). The active phase of the collision deformation terminated at the end of the Early Carboniferous by the disintegration of the nappe slabs by left shears. The final structural separation of the Akkermanovka fragment is believed to have been associated with post-Cretaceous faults. INDEX TERMS: 1021 Geochemistry: Composition of the oceanic crust; 1036 Geochemistry: Magma chamber processes; 3042 Marine Geology and Geophysics: Ophiolites; 3643 Mineralogy and Petrology: Layered magma chambers; KEYWORDS: Ophiolites, oceanic crust, spreading, layered rocks, sheeted dikes, Khabarny Massif, Akkermanovka rock association, South Ural.

Citation: Razumovskiy, A. A. (2006), The geologic structure of the Akkermanovka fragment of the Khabarny Massif ophiolite association (South Ural), Russ. J. Earth. Sci., 8, ES3004, doi:10.2205/2006ES000205.

\section{Introduction}

[2] In the limits of the present-day fold structure of the Ural, most of the ophiolite zones are located conformably with the submeridional structural zones of the Uralides. The least disintegrated and wholly preserved ophiolite sequences

Copyright 2006 by the Russian Journal of Earth Sciences. ISSN: 1681-1208 (online) are exposed in the massifs restricted to large tectonic sutures. The largest ophiolite belt, more than $2000 \mathrm{~km}$ long, from $48^{\circ} \mathrm{N}$ to $68^{\circ} \mathrm{N}$, marks the suture zone of the Main Ural Fault, separating the western segment of the Uralides from the deformed edge of the East European Craton. The South Ural segment of this belt includes the largest massifs of the region, which are wholly or partially composed of the rocks of the ophiolite association, namely, the Khalilov, Khabarny, Kempirsai, and Daul-Kokpekty massifs, the latter being buried under the loose deposits. 
[3] The study of the basic-ultrabasic rocks of the Ural began by the end of the XIX to the beginning of the XX century and was associated with the names of E. S. Fedorov, F. Yu. Levinson-Lessing, and L. Dyupark. The modern period of the active study of the Ural ophiolites stems from the beginning of 1969, when the well-known paper of A. V. Peive, namely, "The Oceanic Crust of the Geological Past" was published in 1969 [Peive, 1969], and a number of other papers were published in terms of lithospheric plate tectonics [Coleman, 1971; Dewey and Bird, 1971; Moores and Vine, 1971; to name but a few]. Since that time huge amounts of data were accumulated. For instance, more than 150 papers were published on the geology of the Khabarny Massif. This massif is believed to be the best known in the Ural region, and is often used in the literature as a standard in comparing the ophiolite massifs both in the Ural region and elsewhere. Yet, in spite of its formally very good knowledge, the geology of the Khabarny Massif still has many unsolved problems. Some of them are principally important both for the understanding of the structure and geologic history of this massif, and for the reconstruction of the Early-Middle Paleozoic geodynamic evolution of the entire region.

[4] For instance, I. V. Semenov [Semenov, 2000; Semenov et al., 1980] believes that the emplacement of the sheeted dikes of the ophiolite association of the Khabarny Massif took place under MOR conditions, whereas other authors provide evidence in favor of the island-arc nature of this rock complex [Maegov, 1984; Pushkarev and Khazova, 1991]. Some of the rocks of the East Khabarny association of the Khabarny Massif are ranked as ophiolites by some authors [Paneyakh, 1989; Peive et al., 1971; Perfiliev, 1979; Savelieva et al., 2005; to name but a few]. Other authors prove their analogy to the rocks of the Platinum-bearing Ural Belt [Balykin et al., 1991; Pushkarev and Fershtater, 1995; Pushkarev et al., 1996; Varlakov, 1966; to name but a few]. Some authors provide information to prove the intrusion of the East Khabarny association bodies into the granulite-facies volcanogenic terrigenous rocks which composed the basement of the continental crust (apobasalt amphibolite, garnet amphibolite, quartzite, quartz gneiss, garnet-phengite-quartz-feldspar schists, and other rocks) [Biryuzova and Pushkarev, 2004; to name but a few]. Views also differ greatly concerning the timing of the spreadingtype rock complexes of the Khabarny ophiolites, namely, from the Middle Ordovician [Ivanov, 1988, 1998], to the Early Silurian-Middle Devonian [Semenov, 2000], to the Late Silurian-Early Devonian [Balykin et al., 1991; Krasnobaev et al., 2004; Pushkarev and Kaleganov, 1993], to the EarlyMiddle Devonian [Savelieva et al., 2005; to name but a few].

[5] One of the reasons for these contradictions may be, on the one hand, the above mentioned abundance of data, obtained in different periods of time, using different methods, and interpreted following the concepts available, and on the other hand, the one-sided study of the objects, usually emphasizing the matter characteristics of some or other rocks and/or rock complexes. In this connection we deal with the situation where some of the Khabarny rocks have been studied well in terms of their petrology, but are devoid of their modern geostructural characteristics. One of these objects is the Akkermanovka fragment of the Khabarny Massif which has not been studied as an integral object, or as one and indivisible fragment of the ophiolite rock sequence.

[6] The aim of this paper is to provide the summarized characteristics of the Akkermanovka fragment of the Khabarny Massif ophiolite association, to show its position in the general structure of the surrounding volcanogenic sedimentary country rocks, and to discuss the rocks of this fragment not only as petro-structural units, but also as a part of the general rock sequence of the paleooceanic crust.

\section{Geologic Position and General Structure of the Khabarny Massif}

[7] The rocks of the Khabarny Massif, filling a structural saddle (synform) between the southern Uraltau subsidence and the northern pericline of the Ebetin antiform (Figure 1), compose an allochthon slab in the package of the tectonic nappes of the Paleozoic volcanic sedimentary rocks of the Sakmara allochthon (forming a zone of the same name) of the South Ural mountain belt [Kamaletdinov and Kazantseva, 1970; Peive et al., 1971; Ruzhentsev, 1976]. In the west, the rocks of the Khabarny allochthon are thrust over the Ordovician-Devonian volcanogenic sedimentary rocks in the central part of the Sakmara Zone [Peive et al., 1971; Ruzhentsev, 1976, 2005; to mention but a few]. In the west the rocks of the Khabarny allochthon are thrust over the Ordovician-Devonian volcanogenic sediments in the central part of the Sakmara Zone [Peive et al., 1971; Ruzhentsev, 1976, 2005]. The structure of the western edge of the Khabarny allochthon and of the serpentinite melange zone is complicated by a series of steeply dipping shear faults [Abdulin et al., 1977; Razumovskiy, 2004a, 2004b]. The southern plunging of the Uraltau and the northern plunge of the Ebetin antiform are composed of the metamorphosed and intricately dislocated rock complexes, participating in the structure of the Sakmara and Sakmara-Voznesensk zones [Borisenok and Ryazantsev, 2005; Borisenok et al., 2002; Puchkov, 2000]. The overthrust character of the boundaries between the Khabarny Massif and these rock complexes was reported by many geologists [Kheraskov, 1971; Shcherbakov, 1990; to name but a few].

[8] Enveloping the periclines of the antiforms discussed, the allochthonous rocks of the Khabarny Massif join, in the east, the submeridional suture zone of the Main Ural Fault. This suture zone, also known as the Sakmara-Voznesensk Zone, is distinguished by a system of seismic reflectors, dipping to the east at the angles close to $60^{\circ}$ and decreasing to $30-25^{\circ}$ at a depth of about $35 \mathrm{~km}$ [Morozov, 2001]. This zone is usually treated as a root suture for the Sakmara and Kraka nappes [Kamaletdinov, 1974; Ruzhentsev, 1976; and many other publications]. The western limitation of this suture zone in the region discussed is the East Uraltau fault. This fault had broken off the Akkermanovka fragment from the main body of the Khabarny Massif. Northward, east of Uraltau, this fault is marked by the outcrops of serpentinites and by the rocks of the sheeted dike complex (Uzembaev 


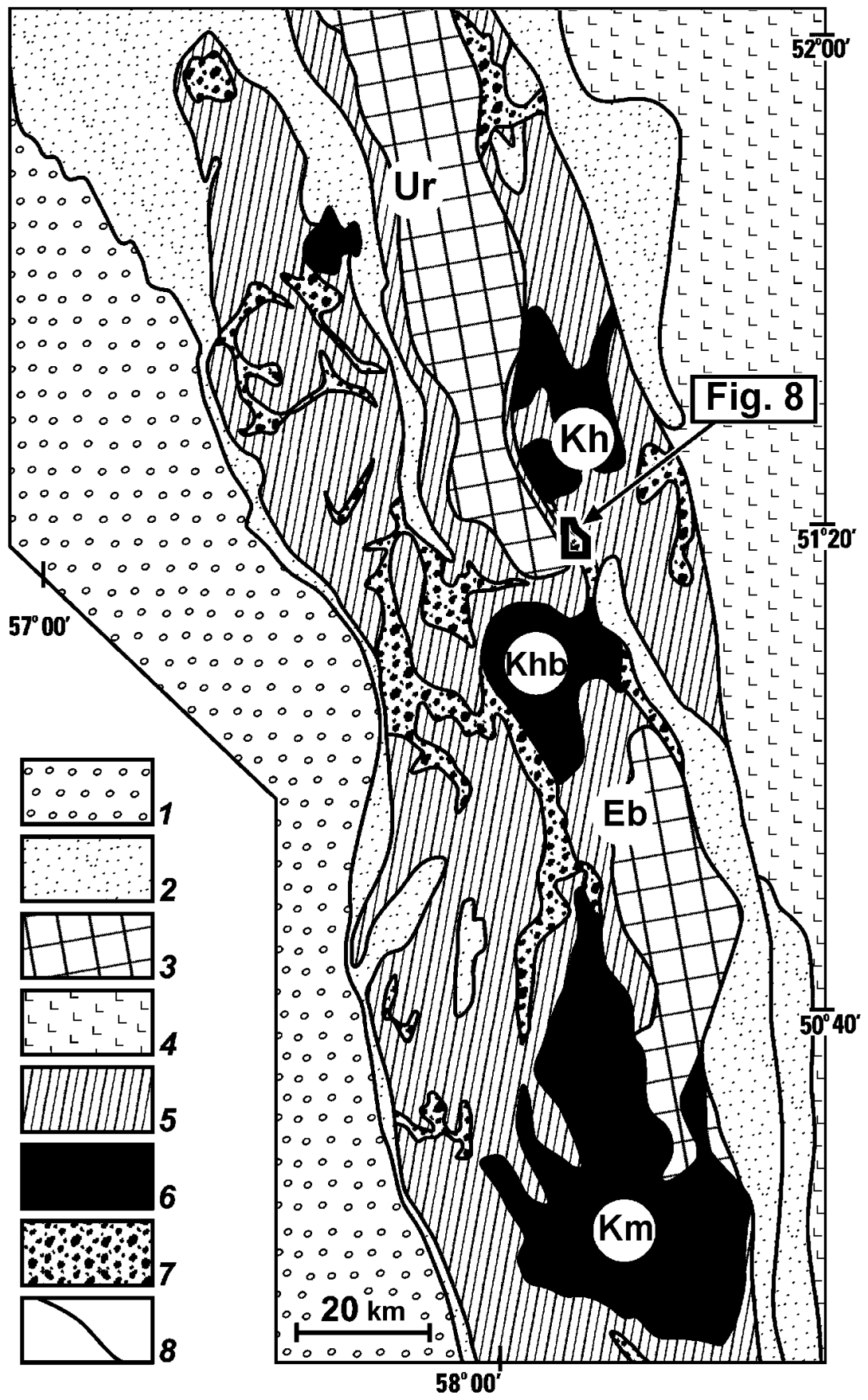

Figure 1. The schematic positions of the main structural elements of the Paleozoides in the western part of the South Ural region, simplified and modified after [Peive et al., 1977; Ruzhentsev, 1976; Ryazantsev et al., 2005; Sobolev, 1979]): (1) flysch deposits in the eastern side of the internal depression of the foreUral marginal trough $\left(\mathrm{C}_{2}-\mathrm{P}_{1}\right) ;(2)$ graywacke flysch of the Zilair Series $\left(\mathrm{D}_{3}-\mathrm{C}_{1} \mathrm{t}\right)$; $(3)$ Precambrian and Paleozoic metamorphic rocks (Maksyutov Complex and its analogs); (4) Devonian volcanic and epiclastic rocks in the western part of the Magnitogorsk Zone; (5-7) the rock complexes of the Sakmara (in the west) and Sakmara-Voznesensk (in the east) zones $\left(\mathrm{O}_{1}-\mathrm{C}_{1}\right)$ : (5) terrigenous, volcanic, tuffaceous-volcanic, siliceous, tuffaceous-silicic, and olistostrome rocks; (6) basic-ultrabasic rocks; (7) tectonic sedimentary serpentinite melange; (8) boundaries of the main structural elements. The letters denote the structural fragments of the Central Ural megazone: (Ur) Uraltau antiform, (Eb) Ebetian antiform, Khalilov (Kh), Khabarny (Khb) and Kempirsai (Km) basic-ultrabasic rock massifs. 
fragment of the sheeted dike complex) [Razumovskiy, 2006]. Farther northward, this fault divides the ultrabasic rocks of the Khalilov Massif from the Uraltau metamorphic rocks. Here, in the vicinity of the Mazovo Settlement, this fault zone is represented by a series of parallel ruptures bordering the blocks of pyroxenite, layered gabbroids, parallel diabase dikes, and ophicalcite [Borisenok and Ryazantsev, 2005]. Hence, in spite of the fact that the Akkermanovka fragment is interpreted historically, because of its spatial compatibility and the petrographical identity of its rocks, as a part of the Khabarny massif, it is actually located in the root zone of the Khabarny allochthone [Peive et al., 1971; Perfiliev, 1979; Ruzhentsev, 1976, 2005; Ruzhentsev and Savelieva, 2003; to name but a few].

[9] The Khabarny Massif itself is composed of maficultramafic rocks of different geodynamic origins (Figure 2). The lower structural position is occupied by the rocks of a stratified pluton of a dunite-clinopyroxenite-websteritegabbronorite (East Khabarny) association. Structurally higher are the rocks of the ophiolite association. The East Khabarny rock association is represented by dunite and olivine clinopyroxenites, normally replacing one another from the top to the bottom (in modern bedding), with less developed wehrlite and olivinite, amphibole and amphibole-plagioclase websterite, including gabbroid bodies, and also usually common biotite and orthoclase gabbronorite [Balykin et al., 1991; Fershtater et al., 1982; Pushkarev and Fershtater, 1995; to name but a few]. The gabbronorite portion of the pluton was found to contain harzburgite and amphibolite xenoliths [Balykin et al., 1991; Biryuzova and Pushkarev, 2004].

[10] The Khabarny ophiolite sequence includes the rocks of the upper mantle (mantle tectonites known as the restite portion of the rock sequence), and also the crustal rock complexes composed of lower-crust plutonic rocks (layered rock complex) and hypabyssal rocks (upper gabbro, sheeted dike complex, and volcanic rock complex). The restite portion of this ophiolite sequence is represented by a duniteharzburgite complex, mostly composed of harzburgite, the dunite and vein pyroxenite accounting for not more than $5 \%$ [Shcherbakov, 1990]. Still less developed is lherzolite [Gottman, 1997; Pushkarev, 1998]. The crustal ophiolites are known in the western part of the Khabarny Massif between the Guberlya and Ural rivers, in the Kirpichnaya and Medyanka ravines, and also at the eastern edge of this massif, at the upper reaches of the Topkaya, Razboika, and Banka rivers, where the Akkermanovka ophiolite fragment was mapped (see Figure 2). On the whole, the crustal part of this rock sequence includes a layered rock complex, an intrusive hypabyssal gabbro-plagiogranite association (the zone of the upper magma source) and its dike and volcanic rock complexes [Fershtater et al., 1982; Kopteva et al., 1979; Maegov, 1977; Razumovskiy and Astrakhantsev, 2005 ; to name but a few]. The fact that the rocks composing the two fragments discussed belong to the same ophiolite sequence can be ranked as an absolute fact. Many geologists emphasized the identity of the petrographic, petrochemical, and geochemical compositions of the rocks composing the layered and sheeted dike rock complexes in the Kirpichnyi fragment to the respective rocks developed in the area of the Akkermanovka fragment, and a distinct difference of the layered ophiolite rock complex from the respective homologs in the East Khabarny association [Fershtater, 2004; Fershtater et al., 1982, 1998; Khvorov et al., 1971; Maegov, 1977; Varlakov, 1978].

[11] The rocks of the dunite-harzburgite complex are cut by small ring and dike intrusions, known as the Molostov Complex. These intrusions are composed of olivine and olivine-hornblende clinopyroxenites, gabbroids, hornblendite, and granitoids. These rock massifs are usually treated as the apophyses of the East Khabarny stratiform deposit produced by water-saturated and less viscous melt [Balykin et al., 1991; Fershtater et al., 1982].

[12] Both, the ophiolites and the rocks of the EastKhabarny association are cut by long dikes, known as the complex of gabbro-diabase veins which also intersect the basement amphibolites and extend into the allochthon frame [Khvorov et al., 1971; Maegov, 1977; Shcherbakov, 1990; to name but a few].

\section{The History of Studying the Akkermanovka Fragment of the Khabarny Massif}

[13] The geological structure of the Khabarny Massif and its country rocks was described in a few hundreds of papers, a review of which is beyond the scope of this paper. Mentioned below are the results of the researchers who studied the Akkermanovka fragment of the Khabarny Massif.

[14] Initially, the Akkermanovka rock association was treated as an independent differentiated intrusion, ranging from ultrabasic rocks in its lower part to plagiogranite in the upper [Varlakov, 1978; Varlakov and Matveev, 1978; Varlakov et al., 1967]. Later, Maegov [1977] and other geologists proved that the mafic-ultramafic rocks of this rock association had belonged to the layered rock complex, and the plagiogranites, to the dike complex of the ophiolites [Maegov, 1977; to name but a few].

[15] A view was advanced that the Akkermanovka fragment was a zone of serpentinite melange cut by intrusive rock bodies and gabbro veins, concordant with the strike of the tectonic zone [Shcherbakov, 1990]. The rocks of the stratified rock complex were described as an older complex relative to the dunite-harzburgite "stratiform gabbronorite-peridotite complex" and were interpreted as "the upper parts (or tectonically detached masses) of a mantle diapir, intensively deformed by tectonic activity" [Tishchenko and Smirnova, 1995]. The formation of the Akkermanovka layered rock complex was treated as the result of the Fe-Mg metasomatism of the gabbroids and the adjacent alpine-type ultrabasic rocks [Varlakov, 1996]. There is another view on the emplacement of the layered rocks of the Akkermanovka and Kirpichnyi fragments "after the obduction of the harzburgite over the rocks of the continental margin and island-arc crust" in the environment of a back-arc supra-subduction spreading basin [Fershtater, 2003, 2004; Fershtater et al., 1998].

[16] The complex of sheeted dikes in the Akkermanovka 


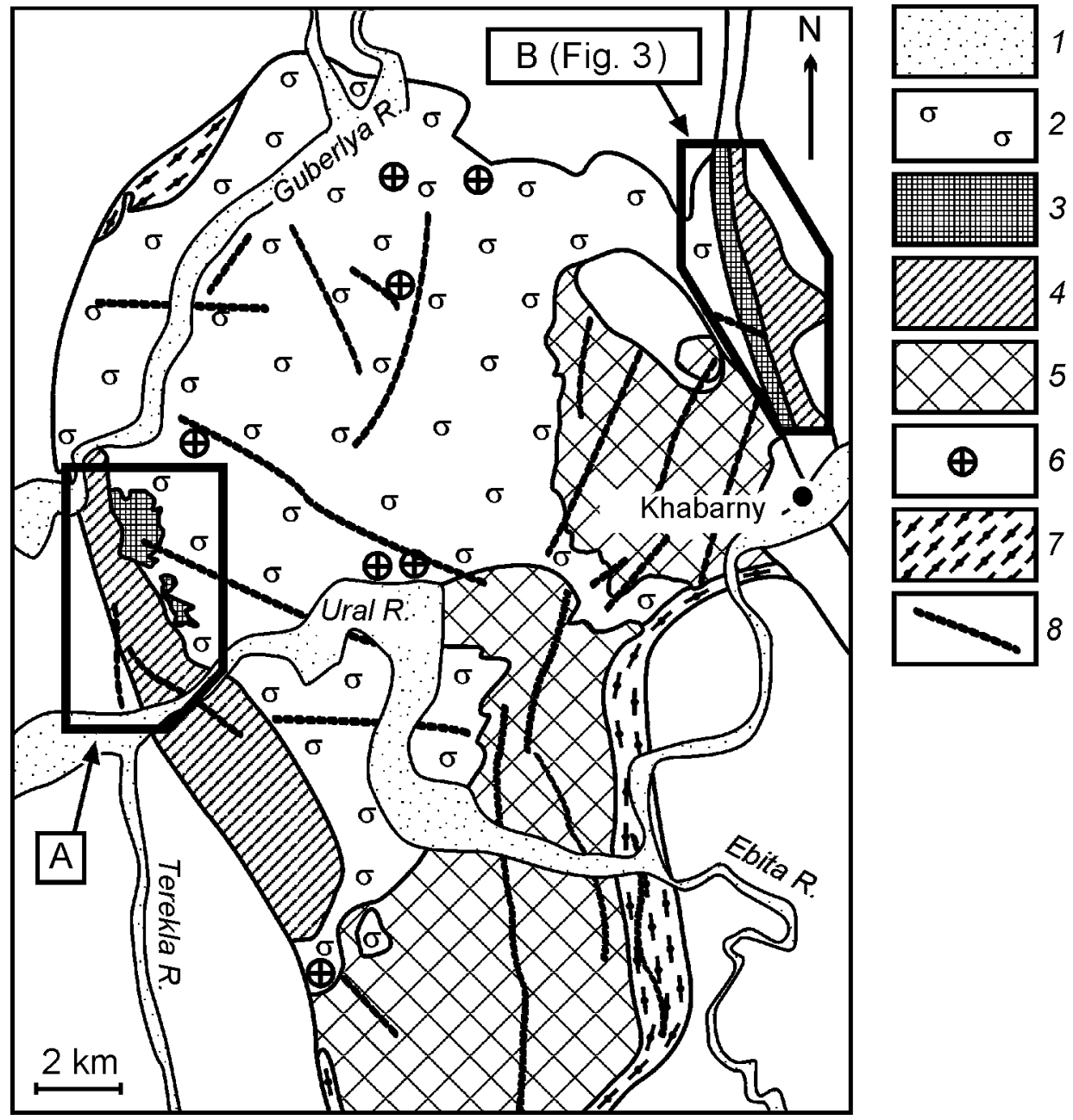

Figure 2. The schematic geological map of the Khabarny Massif, simplified and modified after [Fershtater et al., 1982; Khvorov et al., 1971; Shcherbakov, 1990]. (1) Quaternary alluvial deposits; (2-4) rocks of the ophiolite association: (2) dunite-hartzburgite complex, (3) layered rock complex, (4) sheeted dike and volcanic complex, (5) East Khabarny dunite-clinopyroxenite-websterite-gabbronorite association, (6) intrusions of the Molostov Complex (not-to-scale), (7) amphibolite, (8) late (neoautochthonous) dikes of vein-type gabbro-diabase. Shown in frames are the positions of the areas of the development of the ophiolite crustal rocks: (A) in the western part of the Khabarny Massif, between the Guberlya and Ural rivers, the Kirpichnaya and Medyanka ravines (Kirpichnyi fragment); (B) the eastern edge of the Khabarny Massif, and the upper reaches of the Topkaya, Razboika, and Banka rivers (Akkermanovka fragment). Frame B corresponds to the area shown in Figure 3.

fragment was described as the Eifelian "Khabarny-Karatugay volcanic neck zone" restricted to the Main Ural Fault, where four intrusion phases have been identified: Phase 1 of gabbrodiorite, microgabbro-porphyrite, microgabbrodioriteporphyrite; phase 2 of rhyolite and quartz porphyry, plagiogranite-porphyry, plagiogranite, and plagiogranodiorite; phase 3 of plagiogranodiorite-porphyry, plagiogranodiorite, diorite-porphyry, and phase 4 of rhyolite, quartz porphyry, rhyodacite, and granite porphyry [Tishchenko and Smirnova, 1995; Tishchenko et al., 1983].

\section{Geologic Structure of the Akkermanovka Fragment}

[17] As a result of this study, a geological map was plotted for the central and northern parts of the Akkermanovka fragment (Figure 3). The rocks composing it occur as a tectonic slab of variable thickness and extend for about $8 \mathrm{~km}$ from NNW to SSE with the general eastern dip at the angles of $40-60^{\circ}$. Like in the Kirpichnyi fragment, the rocks 


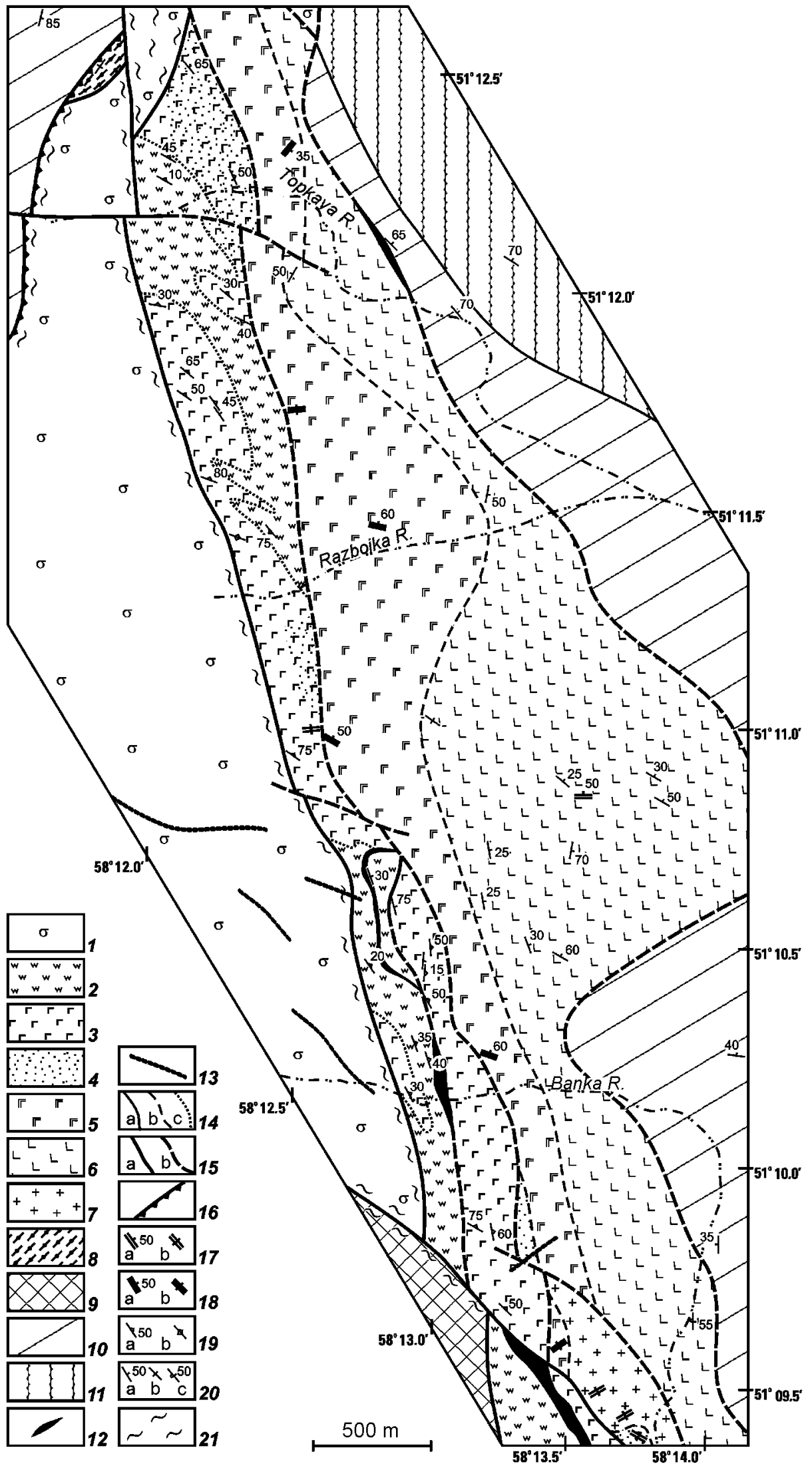


of this layered complex are clearly shown in the geophysical maps as local, positive, high magnetic anomalies (up to 1000 gammas). Also restricted to the layered rock complex, and to the dikes and volcanic rocks of the Kirpichnyi fragment, is a large positive gravity anomaly [Khvorov et al., 1971; Tishchenko et al., 1983; Varlakov et al., 1967].

\section{Layered Rock Complex}

[18] The western contact between the layered rocks of the Akkermanovka fragment and the apohartzburgite serpentinites follows the clearly expressed fault zone, a few meters wide (East Uraltau Fault). In this fault zone both the apohartzburgite serpentinites and the rocks of the layered rock complex are highly schistose with mylonites developed sporadically at their contact. It should be noted that pyroxenite and gabbroid veins, ranging from a few tens of centimeters to 1-2 $\mathrm{m}$ in width and having a visible length of up to $10 \mathrm{~m}$, are developed in the rocks of a dunite-harzburgite complex, in the zone a few hundred meters thick. The composition of these veins is similar to the composition of the rocks in the Akkermanovka layered rock fragment, which proves the primary intrusive contact between the layered rock complex and the restite. This conclusion is supported by the direct analogy with the bodies composed of the rocks of the layered rock complex, exposed in the west of the allochthon between the Guberlya and Ural rivers (Kirpichnaya Ravine), where a large number of apotheses and vein flakes of the intrusions were found in the serpentinized dunite and harzburgite. This fact was repeatedly mentioned by previous investigators [Fershtater, 2004; Fershtater et al., 1982; Maegov, 1977; Varlakov, 1978] and proved by our data.

[19] The rocks of the layered complex in the Akkermanovka fragment are represented by wehrlite (and/or by plagioclase wehrlite), olivine clinopyroxenite, and clinopyroxenite. Much more rare rocks are websterite, olivine gabbro, gabbronorite (occasional gabbro), and amphibole gabbro. All of these rocks, with the exception of amphibole gabbro, can be connected with one another by gradual transitions, producing banded and schlieren-banded fragments of the same layered rock complex (in the upper reaches of the Topkaya and Razboika rivers), and can compose independent blocks, a few hundred meters thick, separated from the overlying and underlying rocks by faults (in the areas between the Razboika and Banka rivers and in the upper reaches of the Banka River). The amphibole gabbro is developed in some local areas in the upper reaches of the Topkaya River and south of the Razboika $R$. upper reaches. These rocks often contain clinopyroxene relics, being the products of gabbronorite transformation [Maegov, 1977].

[20] The layering of the plutonic rocks, characterized by varying-scale banding depicting the open linear folds of the sublatitudinal and NW strikes, is most clearly expressed in the northern part of the Akkermanovka fragment between the Topkaya and Razboika rivers. The banding itself has been caused by the quantity variation of the rock-forming minerals and also by the granularity variation in the layers of the same mineral composition. The thicknesses of the layers differing in composition may be $10-15 \mathrm{~cm}$ (see Figure 4), and also $8-10$ or even $15 \mathrm{~m}$, where the layering is less intensive. The thicknesses of the layers differing in grain size, with the same mineral composition, usually vary from $4-5 \mathrm{~cm}$ to $40-50 \mathrm{~cm}$. The interbeds composed of wehrlite and clinopyroxenite may include gabbronorite veins, the first dozens of centimeters thick, which cut the banding at the angles of $30-40^{\circ}$. There are also later sealing veins $2.5-4 \mathrm{~cm}$ thick. The latest of them are pegmatoid gabbro veins (see Figure 5) whose thickness varies from $1.5 \mathrm{~cm}$ to $15 \mathrm{~cm}$. The composition of the gabbro "pegmatites" correlates with the composition of their country rocks; the veins intruded into gabbronorite have the same gabbronorite composition, the pegmatoid veins intruded into olivine gabbro and wehrlite have the same olivine-gabbro composition (the latter fact was described by Maegov [1977] and confirmed by our data.

[21] In the central part of the Akkermanovka fragment (Banka R. area), the rocks of the layered complex are tectonized and broken into blocks composed usually of ultrabasic rocks or gabbroids. The areas between the blocks of-

Figure 3. The schematic geological map of the northeastern part of the Khabarny Massif, plotted using the data reported by [Khvorov et al, 1971; Maegov, 1977; Varlakov and Matveev, 1978]. (1) undifferentiated serpentinized dunite and hartzburgite; $(2,3)$ the rocks of the layered complex: $(2)$ dominated by clinopyroxenite, olivine clinopyroxenite, wehrlite, and olivine gabbro, (3) dominated by gabbronorite and gabbro; (4) zones of gabbronorite amphibolitization and amphibole gabbro development; (5) sheeted dike complex: gabbro-diabase, diabase, and diorite dikes; (6) volcanic rocks: basalt, basaltic andesite, tuff and tuffaceous conglomerate breccias; (7) plagiogranite and quartz diorite; (8) amphibolite; (9) undifferentiated rocks of the East Khabarny rock association; (10) undifferentiated Early and Middle Paleozoic volcanic sediments; (11) undifferentiated Devonian and Carboniferous sedimentary rocks; (12) faultbordering serpentinite bodies and serpentinite melange zones; (13) late (neoautochthonous) dikes of vein type gabbro-diabase; (14) geological boundaries: (a) proved, (b) inferred, (c) gradual; (15) faults: (a) proved, (b) inferred; (16) overthrusts; (17) dips and strikes of single diabase dikes: (a) inclined, (b) vertical; (18) dips and strikes of the diabase and gabbro-diabase packages of the sheeted dike complex: (a) inclined, (b) vertical; (19) dips and strikes of the striation in the layered rocks: (a) inclined, (b) vertical; (20) dips and strikes of the layering for the volcanic rocks, of striation, for the amphibolites, and mineral schistosity of the pyroxene for the gabbroids of the layered complex: (a) inclined, (b) vertical, (c) overturned; (21) schistosity zone. All coordinates are given in the Pulkovo system, 1942. 


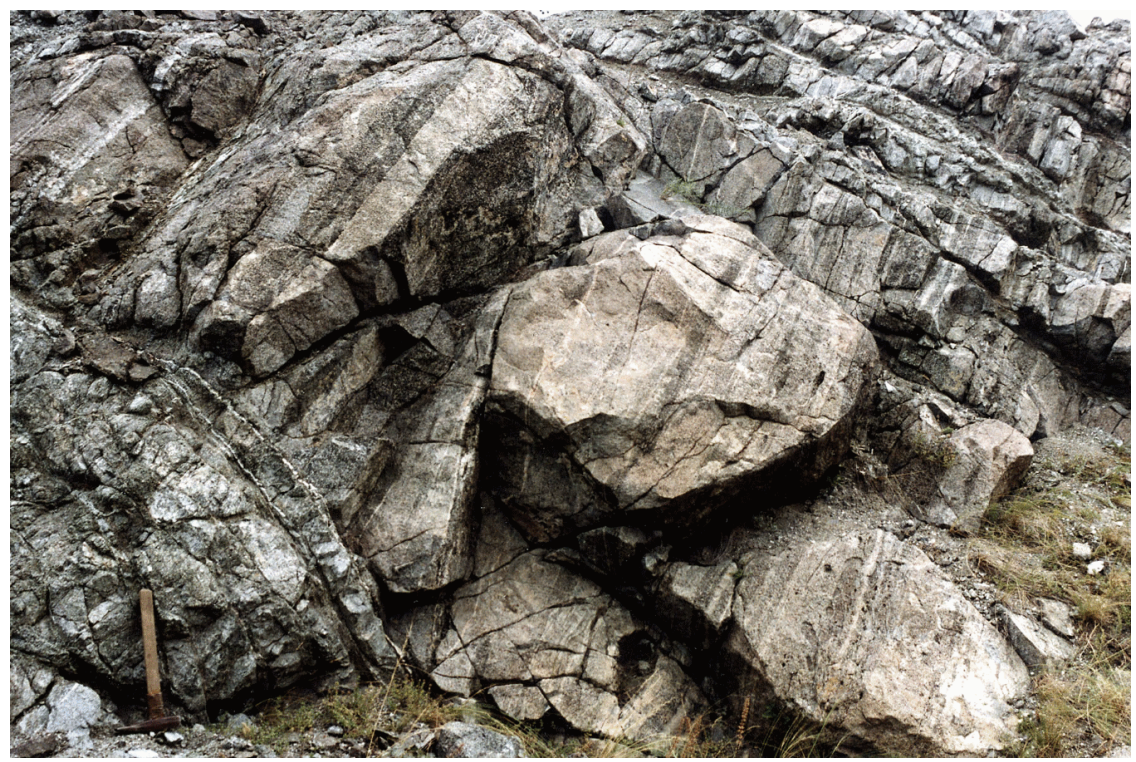

Figure 4. Mineral striation in the rocks of the layered complex. The former rail-way excavation in the upper reaches of the Topkaya and Razboika rivers.

ten contain lenses of apodunite and apohartzburgite serpentinites and serpentinite schists. The banding of the rocks is preserved inside the blocks. Most of the schlierens and interlayers, differing in grain size, differ also in lithology, this difference being caused by a change in the amount of darkcolor minerals.

[22] The olivine clinopyroxenite, clinopyroxenite, and wehrlite usually occur in the same areas, being connected with one another by mutual transitions. There are both massive and schlieren-banded varieties. These are mediumand large-grained, occasionally, giant-grained varieties of a poikilitic texture with clinopyroxene crystals containing nearly isometric olivine grains. Their olivine is serpentinized to different extents, the lizardite sectors being usually separated by the chains of fine-grained magnetite. Idiomorphic chrome spinellid grains occur in wehrlite as an accessory mineral. Plagiowehrlite appears in the vicinity of the transitions to olivine gabbro. Of all minerals, plagioclase is most xenomorphic, being almost wholly saussuritized. Websterite is rarely found being restricted to thin, schlieren-type interlayers in the clinopyroxenite, its orthopyroxene being represented as bronzite. The olivine gabbro is usually represented by its coarse-grained variety, usually banded and rarely massive. Along with olivine, clinopyroxene, and plagioclase,

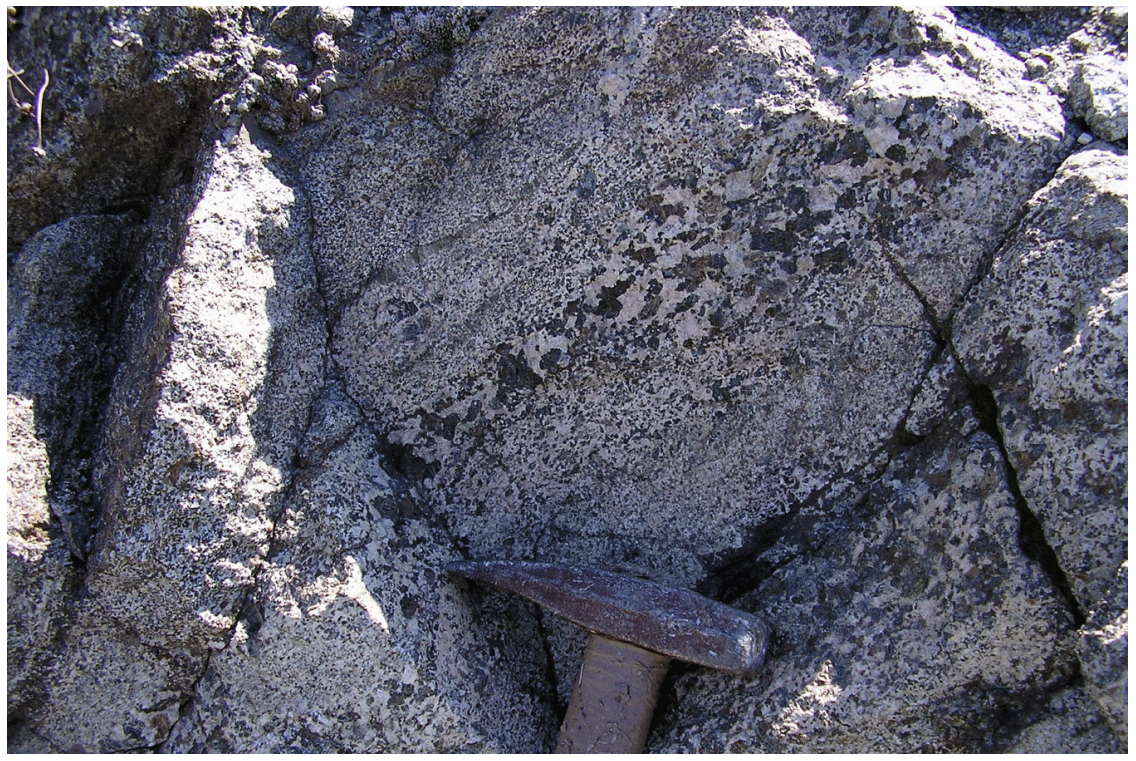

Figure 5. Pegmatoid gabbro veins in gabbronorites. The former rail-way excavation in the area between the upper reaches of the Topkaya and Razboika rivers. Photographed by A. V. Ryazantsev. 


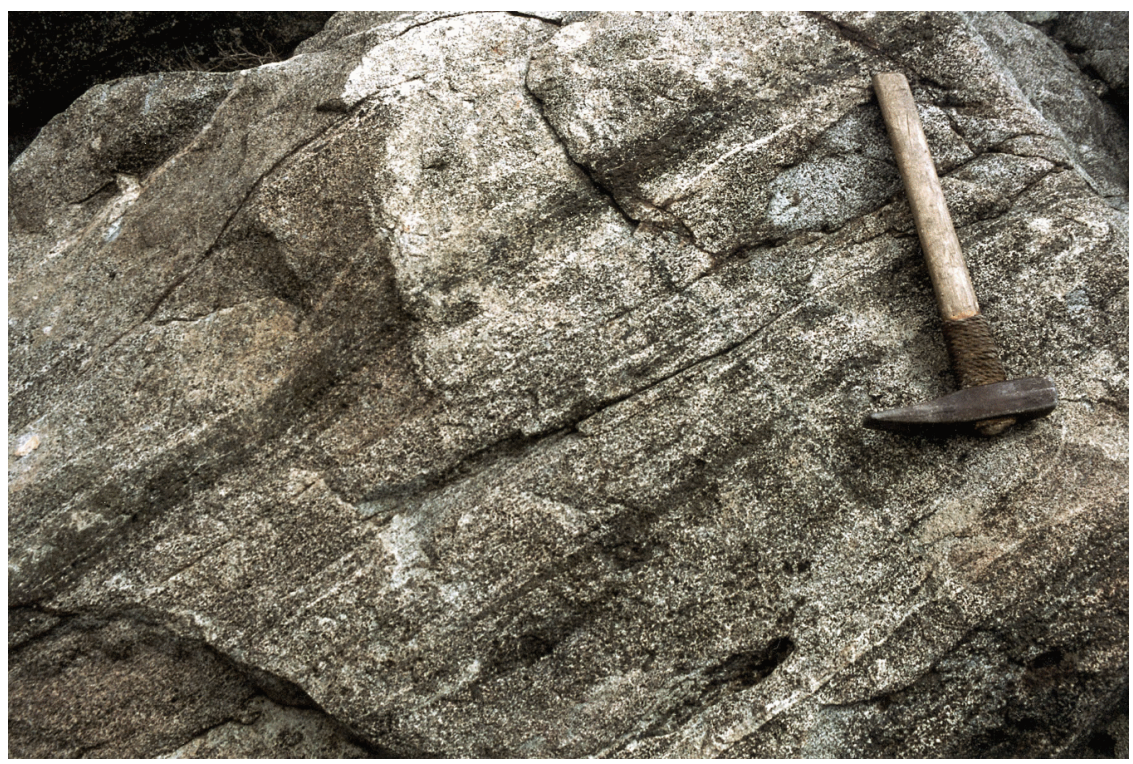

Figure 6. Banded gabbronorite in the former rail-way excavation between the upper reaches of the Topkaya and Razboika rivers.

found in some areas is orthopyroxene (bronzite), and the rock acquires an allotriomorphic-granular (gabbroid) structure. The secondary minerals are represented by an aggregate of iddingsite, lizardite, and magnetite, the plagioclase is serpentinized, and zoicite is developed. The gabbronorite is a medium- to coarse-grained rock, occasionally banded (Figure 6); less common are its massive varieties, the rocks having a gabbro structure. The plagioclase is represented by its bytownite variety, the ore mineral, by xenomorphic titanomagnetite. The bronzite is replaced by tremolite and talc, the clinopyroxene is uralitized, the plagioclase is replaced by a saussurite aggregate, and zoisite appears. Yet, generally, the degree of secondary alterations is not high. The amphibole gabbro to medium-coarse grained rocks may contain epidote and quartz as accessory minerals. The rocks have a poikiloblastic structure, their elongated plagioclase grains are enclosed into hornblende, the latter often containing ortho- and clinopyroxene relicts. The central zones of the plagioclase grains are saussuritized.

\section{The Complex of Sheeted Dikes}

[23] East of the outcrops of the peridotite-pyroxenites and gabbroids, the tectonic contact between the layered rock complex and the rocks of the sheeted dike complex is not exposed along its entire length. Yet, it can be traced by a change in the alluvial state of the rocks. The rocks of the layered complex, mainly gabbronorites, with numerous diabase dikes and single plagiogranite veins, are brought tectonically together with the packages of sheeted dikes, among which single gabbronorite screens, $25-30 \mathrm{~cm}$ in thickness, were found in the vicinity of the contact with the layered rock complex. Two small outcrops of fine- to middle-grained taxitic amphibole gabbro outcrops were found in the southern part of the study area (the right side of the Banka $R$. Valley) in the vicinity of the western contact of the sheeted dike complex (see Figure 3). Judging by the petrochemical data, such as the high $\mathrm{SiO}_{2}$ contents (50-51\%), as well as that of the alkalies, the low $\mathrm{MgO}$ and $\mathrm{CaO}$ contents $(6-$ $7 \%$ and about $8 \%$ ), and other parameters, these rocks are highly different from the amphibolized gabbronorite of the layered rock complex. At the same time, the data points of these rocks in petrochemical diagrams coincide with those of the gabbroids participating in the structure of the continuously differentiated gabbro-plagiogranite association at the bottom of the sheeted dike complex in the west of the Khabarny Massif (Kirpichnyi fragment). Similar compositions were found for the rocks composing the dike complex in the Akkermanovka fragment. Its amphibole gabbro bodies are cut by gabbro-diabase dikes and curving aphanite diabase veins.

[24] In the Banka R. area the dike complex includes a large granitoid block intersected by single porphyry diabase dikes. This massif, in its turn, is comparable, in terms of its petrochemical and structural indications, with the respective bodies participating in the structure of the continuously differentiated gabbro-plagiogranite association (Kirpichnyi fragment) [Fershtater et al., 1982; to name but a few].

[25] The rocks of the sheeted dike complex are poorly exposed in the Akkermanovka fragment. The rocks composing the sheeted dike complex are mostly diabase and gabbrodiabase with an ophitic structure and less common porphyry diabase. The sheeted dike packages include numerous gabbrodiorite and diorite bodies. The latter usually have a porphyry structure. The dike widths vary from $1.2 \mathrm{~m}$ to $3 \mathrm{~m}$. The quenching zones of cryptocrystalline structure are usually $3 \mathrm{~cm}$ to $12 \mathrm{~cm}$ wide.

[26] In the north-south direction, the strikes of the dike 


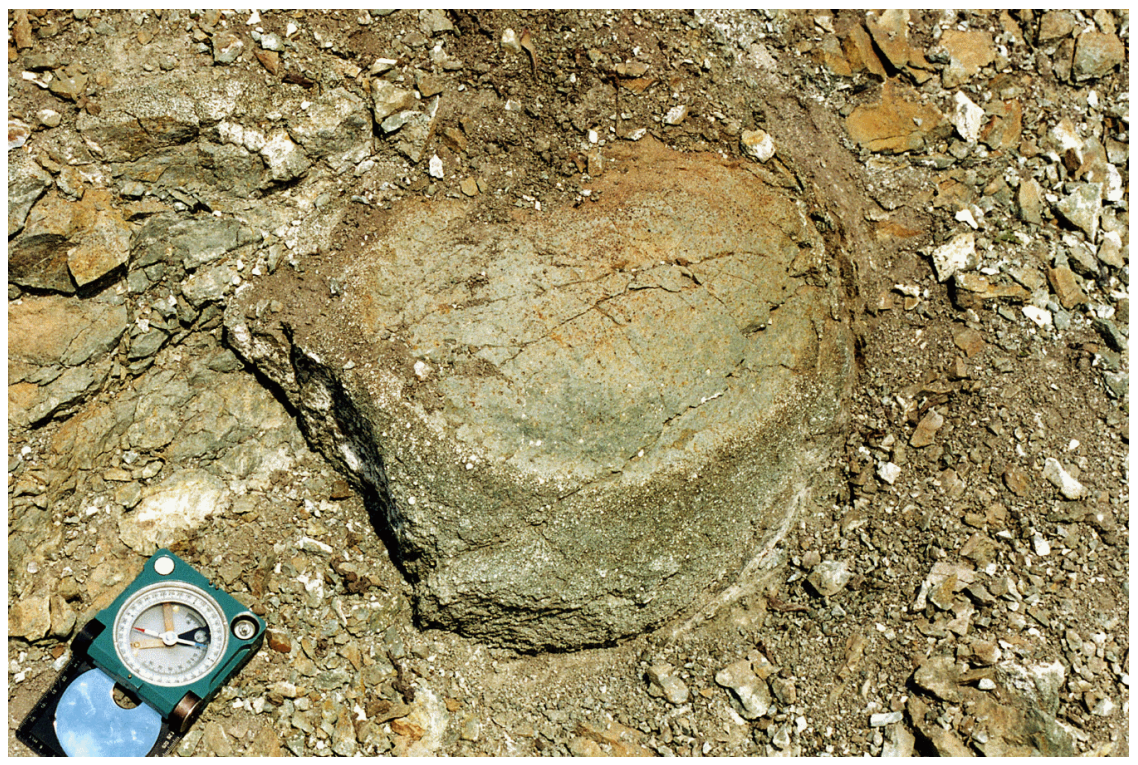

Figure 7. Pillow lavas with almond-rock rims in the left side of the Razboika R. Valley.

packages, dipping to the southeast at the angles of $30-40^{\circ}$ in the north, namely, in the Topkaya $\mathrm{R}$. area, change to sublatitudinal and ESE vertical or steeply dipping $\left(60-70^{\circ}\right)$ in the northern rumbs, southward, in the area of the Razboika River. Between the Razboika and Banka rivers, the contacts of the dike bodies mostly strike to the southeast with $\mathrm{NE}$ dips at the angles of $50-60^{\circ}$. In the area south of the sublatitudinal flow of the Banka River the rocks strike to the northeast with steep subvertical dips in opposite bearings. The directions of the chilled contacts in the studied outcrops are often opposite (opposite quenching) and do not show any visible rules. At the same time a distinct regularity has been established in the change of the strikes of the dike body packages. This does not allow one to admit any superposed tectonic desintegration. It follows that the commonly observed opposite orientation of the quenching zones in the dike packages might have been a primary one, suggesting the variable character of the extension, the small thickness of the packages of dikes with one-sided chilling, and the presence of dikes with both contacts being active (two-sided chilling). Favoring the latter assumption is the frequent finding of the closely spaced petrographically different rock types (gabbro-diabase and pyroxene-porphyry diabase with a microgranular groundmass), which seem to correspond to different dike generations by the analogy with the western well exposed fragment (Medyanka Ravine to the Ural River) [Razumovskiy and Astrakhantsev, 2005].

[27] As has been mentioned above, the rocks of the dike complex outcrop north of the Akkermanovka fragment of the Khabarny Massif and east of Uraltau. We refer to these rocks as the Uzembaev fragment of the sheeted dike complex [Razumovskiy, 2006], which will be discussed in detail below.

\section{Volcanogenic Rock Complex}

[28] Developed in the Akkermanovka fragment, east of the sheeted dike complex, are the rocks of the volcanic rock complex. The contact between them is not exposed, yet, is marked well by a change of the rock material in the eluvium. The sequence of the volcanic rocks is composed of the flows (a few meters thick) of aphyric and amygdaloidal basalts, basaltic andesite, and andesite, sometimes with fragments of a pillow-lava structure. There are highly zoned pillows with the central aphyric part and a marginal zone, $5-6 \mathrm{~cm}$ wide, having an amygdaloidal structure (Figure 7). In this case of the amygdule size varies from $1.5 \mathrm{~mm}$ to $4 \mathrm{~mm}$. They are filled with quartz or with a quartz-albite aggregate. The amygdaloidal volcanic rocks composing massive flows have amygdules filled with carbonate. The lava flows are usually separated by tuff layers, ranging from $0.3 \mathrm{~m}$ to $0.8 \mathrm{~m}$ in thickness, or by tuff conglomerate breccias with unsorted fragments, ranging from $0.5 \mathrm{~cm}$ to $15-20 \mathrm{~cm}$ in size. The volcanic rocks are sometimes cut by gabbro-diabase, diabase, and diorite dikes, usually not more than $1.5 \mathrm{~m}$ thick, which seem to have served as channels for the overlying lava flows. Eastward, the volcanic rocks are overlain tectonically, along a clearly expressed fault zone, along which serpentinite melange lenses, up to 20-30 m thick, are developed, by siliceous-schistose volcanic rocks whose graptolites dated them Early Silurian [Khvorov et al., 1971].

[29] The area where sheeted dikes and volcanic rocks are developed includes brecciation zones accompanied by epidotization, chloritization, and silicification. Restricted to these zones is pyrite and chalcopyrite mineralization, mala- 
chite being most common among the hypergenic minerals. Mineralization of this kind is scarce in the volcanic rocks [Khvorov et al., 1971].

[30] South of the study area, at the left bank of the Ural River, $2.5 \mathrm{~km}$ east of the Kyzylsai settlement, a volcanic rock sequence of similar composition and structure was described. In addition to hyaloclastites, it was found to include red platy jasper interlayers. Found in the latter were Middle Devonian conodonts [Ivanov et al., 1984]. The problem whether this dated rock sequence belongs to the ophiolites of the Akkermanovka fragment calls for further study.

\section{Geologic Structure of the Uzembaev Fragment of the Sheeted Dike Complex}

[31] Approximately $8 \mathrm{~km}$ NNW of the northern end of the area, where the sheeted dikes of the Akkermanovka fragment of the Khabarny Massif are developed, east of the Uraltau Zone (see Figure 1), the serpentinites of the western edge of the Sakmara-Voznesensk Zone include a block of the rocks of the dike complex (Figure 8).

[32] The fragment of the dike rock complex, described below and referred to as the Uzembaev fragment, is located at the right bank of the Guberlya River, about $2-2.5 \mathrm{~km}$ northeast of the Guberlya rail-way station and less than $1 \mathrm{~km}$ west of the Uzembaevo Settlement. The rocks of the sheeted dike complex are exposed in an area of about $2 \mathrm{~km}^{2}$. They contact the rocks of the Guberlya Suite, which compose the south-eastern edge of the Uraltau pericline, along a steeply dipping fault zone, and are replaced by the serpentinite of the internal part of the Sakmara-Voznesensk Zone. In the north and northeast they are overlain conformably by the terrigenous deposits of the western side of the OrskTanalyk depression and in the south and southeast they are hidden under the alluvial deposits of the Guberlya River. The rocks of the dike complex are exposed in many artificial outcrops, namely, in pits and rail-way ditches, compose numerous small natural exposures, their elluvial material being developed everywhere.

[33] The western termination of the Uzembaev fragment of the dike complex extends along a subvertical fault zone (East Uraltau Fault). Traceable along this zone is a chain of lenses composed of serpentinite schist with a maximum thickness of about $50 \mathrm{~m}$. Developed in fragments is aposerpentinite talc schist. The serpentinites often contain fragments of gabbrodiabase and porphyry diabase of the sheeted dike complex, and also of giant-grained pegmatoid amphibole gabbro with amphibole hornblende crystals up to $10-12 \mathrm{~cm}$ in size. The fragments in the melange lenses range from $10-15 \mathrm{~cm}$ to $25-$ $30 \mathrm{~cm}$ in size with the scarce small blocks measuring $1 \mathrm{~m}$ to $1.5 \mathrm{~m}$ in size. Some blocks are composed of apogabbro rodingite. The rocks of the dike complex, bordering the fault zone described, are tectonized and locally intensely schistozed in a band a few tens of meters wide. The rocks of the Guberlya Suite are represented by siliceous tuffite, tuff sandstone, tuff siltstone, and siliceous tuffaceous schist with less common basalt. The rocks of this suite are deformed to linear, largemagnitude folds. The strikes of their limbs are conformable with the strike of the fault zone. The rocks of this formation do not show any notable tectonic reworking, even in the vicinity of their contact zone.

[34] The eastern contact of the Uzembaev fragment also shows its clearly manifested tectonic character. Developed northeast of the contact are greenish-black and bluish massive, and less common schistose apohartzburgite serpentinites. Bordering this contact line is a lens of highly tectonized light green serpentinite $25-30 \mathrm{~m}$ thick with numerous fragments and blocks measuring $20 \times 30-50 \times 80 \mathrm{~cm}$ to a few meters in size. Most of the blocks are composed of massive apohartzburgite serpentinite, with less common gabbrodiabase and coarsegrained pegmatoid amphibole gabbroids. Also composed of gabbroids is a lens, 50-60 m long and 7$10 \mathrm{~m}$ thick, restricted to the melange zone.

[35] Structurally, from the northwest to the southeast, the Uzembaev fragment consists of three blocks differing in the lithology and structure of its sheeted dikes. Generally, these blocks reflect the vertically zoned pattern of the spreading center, which is expressed in the changing quantity and composition of the screens, in the changing petrographic varieties of the rocks, and in the distribution character of the dike package orientations. The boundaries between the blocks seem to be of tectonic origin.

[36] The northwestern block is composed of medium- to fine-grained gabbro-diabase bodies, dominated by aphyric rocks with a microgabbro or ophitic (diabase) structure. There are also single dikes containing scarce porphyry-type clinopyroxene phenocrysts. The latter can be found also in the bodies of equigranular gabbro-diabase. The rocks had been subject to significant secondary alteration: clinopyroxene is preserved as relicts in the newly formed amphibole; the magmatic hornblende is often replaced by actinolite, the plagioclase is highly saussuritized, the rocks being chloritized and slightly silicified. The half-dike thicknesses are $1 \mathrm{~m}$ to $1.5 \mathrm{~m}$, occasionally being $2 \mathrm{~m}$. Some bodies, $1 \mathrm{~m}$ to $1.5 \mathrm{~m}$ thick showed two periods of quenching. The packages of gabbro-diabase dikes cut across the single veins of aphanitic, microgranular, pyroxene-porphyry diabase 0.25 $0.8 \mathrm{~m}$ thick.

[37] The sheeted dike packages show a highly irregular orientation. The opposite quenching trends and different strikes of the dike bodies can be found in one outcrop. The gabbro-diabase bodies showed numerous screens of apohartzburgite serpentinites (Figure 9). In some cases the amount of serpentinite screens accounted for $30-35 \%$ of the dike volume. The minimal thickness of the serpentinite screens is $0.2 \mathrm{~m}$, the average, $1.5 \mathrm{~m}$ to $5 \mathrm{~m}$, and the maximal, 10-12 m. The number of the serpentinite screens declines toward the eastern boundary of the block. Some single screens are composed of pegmatoid amphibole gabbro.

[38] The central position is occupied by a block composed primarily of middle- and fine-grained gabbro-diabase bodies with some packages containing fine-grained pyroxeneporphyry diabase with the ophitic structure of the groundmass. The size of the phenocrysts is usually not more than $0.5 \mathrm{~cm}$, yet, sometimes is more than $1-1.5 \mathrm{~cm}$. Some bodies of medium to fine-grained gabbro-diabase have a marginal (transitional) zone between the central crystallized and the marginal cryptocrystalline quench zones, composed 


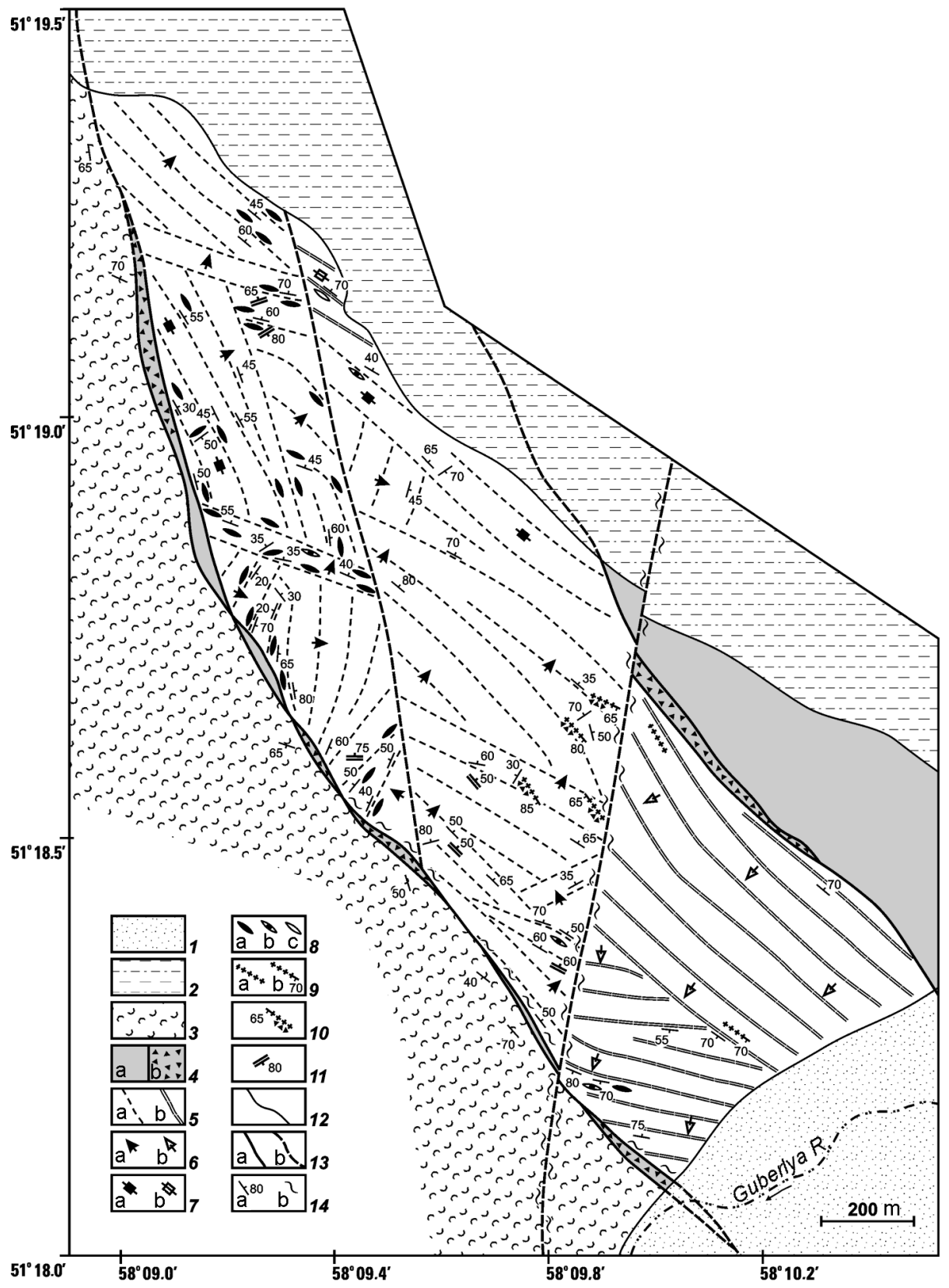

Figure 8. Schematic geological map of a fragment of the Main Ural Fault melange zone in the vicinity of the Uzembaev Settlement, based on the data reported by [Khvorov et al., 1971]. (1) Quaternary alluvial deposits; (2) argillaceous and arenaceous gravelly deposits $\left(\mathrm{J}_{2}\right) ;(3)$ tuffite, tuffaceous sandstone and siltstone, shale and silicic tuffaceous schist, and basalts of the Guberlya Formation $\left(\mathrm{O}_{2-3}\right) ;(4)$ serpentinites: (a) massive apoperidotite serpentinites and serpentinite schists, (b) zones of serpentinite melange; (5-11) sheeted dike complex: (5) strikes of the dike bodies: (a) of early gabbro-diabase generations, (b) of late, mainly fine-grained porphyry diabase; (6) clearly expressed opening trends: (a) for the early gabbrodiabase generations, (b) for the late porphyry-diabase generations; (7) areas of the irregularly emplaced packages with the absence of any expressed opening trends: (a) for the early gabbro-diabase generations, (b) for the late porphyry-diabase generations; (8) (a) serpentinite, (b) gabbroid, and (c) gabbro-diabase screes; (9) granite veins: (a) of indistinct geometry, (b) inclined; (10) breccia zones with granite matrix; (11) aphanitic diabase veins; (12) geologic boundaries; (13) faults: (a) proved, (b) inferred; (14) dips and strikes (a), schistosity zones (b). The coordinates are given in the Pulkovo system, 1942. 


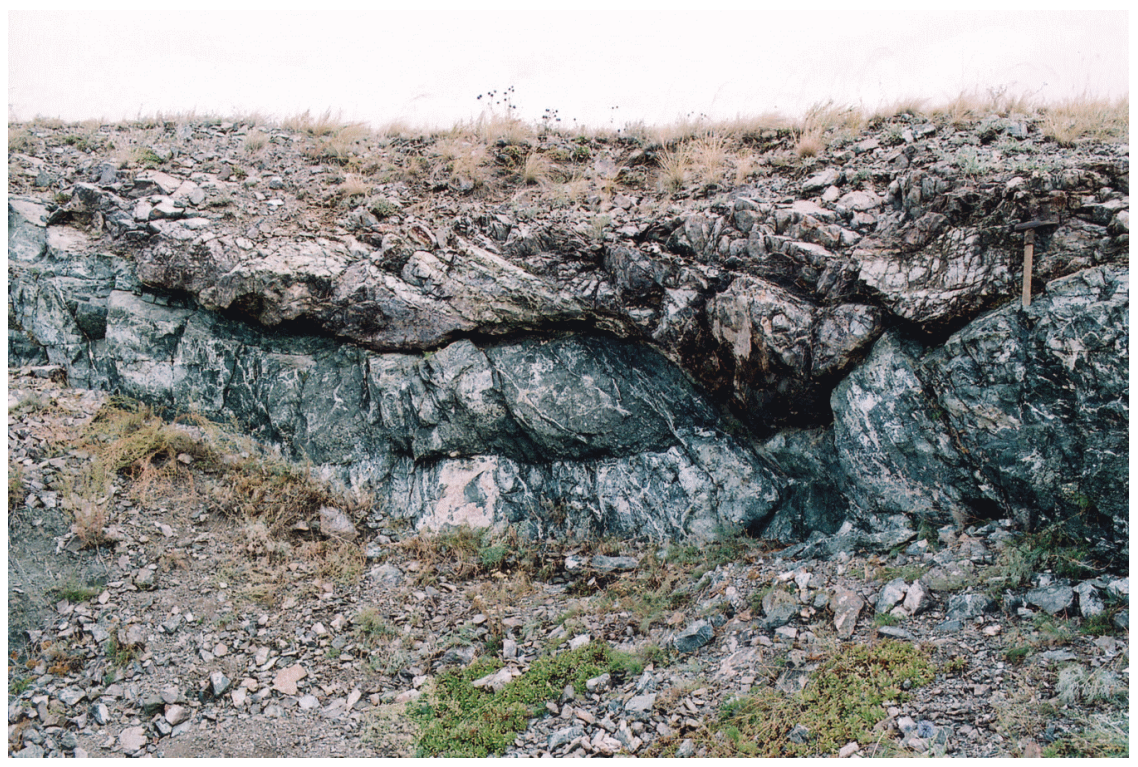

Figure 9. A gently dipping $\left(120-130^{\circ},<20-25^{\circ}\right)$ package of upward oriented single-chilling gabbrodiabase and diabase dikes, including a thick screen of apo-hartsburgite serpentinite (at the top). This rock sequence is disturbed by small-magnitude faults. This is a photograph of a dug pit wall.

of pyroxene-porphyry diabase, its thickness being $20-25 \mathrm{~cm}$. The character of the secondary alteration of these rocks is similar to the type described above, its degree being lower. The thicknesses of the semidikes vary from $0.4 \mathrm{~m}$ to $4 \mathrm{~m}$, the average values being $1.5 \mathrm{~m}$ to $2 \mathrm{~m}$. There are cross-cutting veins and dikes of aphanitic and pyroxene-porphyry diabases from $0.1-0.2 \mathrm{~m}$ to $1.5 \mathrm{~m}$ thick, yet, in contrast to the northwestern block, their bedding is more conformable with the early bodies composing some single-chilling packages.

[39] The orientation of the dikes is more regular than that in the north-western block, the single NNE trend of the opening being more distinct. The single thin $(0.3-0.4 \mathrm{~m})$ screens are composed of medium- to coarse-grained amphibole gabbro. Their oikocrysts include single clinopyroxene relicts. The gabbro is actinolitized and the plagioclase is silicified. Developed in the eastern part of the central block are the zones of cross-cutting granitoid veins which brecciate the gabbro-diabase. The thicknesses of the brecciated rock zones vary from a few centimeters to $0.5-1 \mathrm{~m}$. The northern part of this block is composed of the packages of microgranular pyroxene-porphyry diabase with the screens (passive dikes) of the earlier medium- to fine-grained gabbro-diabase.

[40] The boundary between the central and southeastern blocks extends along the tectonized zone; the rocks of the dike complex are schistosed, mylonite is developed, the fault zone being marked by a topographic scarp. The rocks of the southeastern block are exposed much less than those described above. The elluvial material and scarce bedrock exposures prove the predominance of fine-grained diabase and pyroxene-porphyry diabase, which are often conformable with the general strike of the aphanite diabase vein packages $6 \mathrm{~cm}$ to $8 \mathrm{~cm}$ thick. There are single serpentinite and pegmatoid gabbro screes. The central and northern parts of the block are cut by granitoid veins. A granitoid body in the northern part of the block is more than $5 \mathrm{~m}$ wide and more than $20 \mathrm{~m}$ long. A vein in the central part of the block is composed of syenite-porphyry, its thickness varying from $12 \mathrm{~cm}$ to $4 \mathrm{~cm}$. The southeastern dike block is believed to have the south-southwest opening, that is, the axis of the spreading was located in the northeast in modern coordinates.

[41] As a result of our studies, the following structure was proved for the sheeted dike complex of the Uzembaev fragment. The NW to SE succession of the blocks, composed of the rocks of the dike complex, reflects the vertically zoned structure of the spreading center. Namely, in the northwestern block, up to $35 \%$ of the dike rock volume are occupied by apohartzburgite serpentinite screes. Their volume decreases eastward. In the central and southeastern block they do not compose even $1 \%$ of the dike volume, the gabbroid screes being predominant. From the northwest to the southeast, the rocks composing the dikes change from medium- to fine-grained gabbro-diabase via pyroxene-porphyry gabbrodiabase to fine-grained pyroxene-porphyry and aphanite diabase. Changing in the same direction is the character of the distribution of the dike body orientations from the predominance of the irregularly emplaced packages and headon orientations of the quenching zones in the northwestern block to the single opening trend in the southeastern block.

\section{Discussion of the Results}

[42] The geological and structural data obtained in this study show the similarity of the rocks composing the layeredrock and dike complexes in the Akkermanovka fragment to the respective rocks of the Kirpichnyi fragment in the west 
of the Khabarny allochthon (see Figure 2). This agrees with the conclusions of the previous investigators, based on studying the petrochemical compositions of the rock complexes discussed [Fershtater, 2004; Fershtater et al., 1982, 1998; Khvorov et al., 1971; Maegov, 1977; Varlakov, 1978; to name but a few]. Namely, the plutonic rock complex of the layered peridotite-pyroxenites and gabbroids, the complex of sheeted dikes, and the volcanic rock complex, normally replacing one another from the west to the east in the Akkermanovka fragment, prove their belonging to the same ophiolite association. Moreover, the same rock sequence is preserved in the western part of the Khabarny allochthon (Kirpichnyi fragment). At the same time the rocks of the layered rock complex of the ophiolite association differ significantly from their petrographic analogs composing the East Khabarny dunite-clinopyroxenite-websteritegabbronorite association in the southern and south-eastern parts of the Khabarny Massif.

[43] The plutonic rock complex of the Akkermanovka fragment is characterized by the same layering from olivine pyroxenite-wehrlite to olivine gabbro-gabbronorite. This banding might have been caused both by variations in the quantitative composition of the rock-forming minerals, and by grain-size differentiation in the interbeds of the same mineral composition. The areas with the intensively developed banding (with the thickness of the layers, varying from $10-15 \mathrm{~cm}$ to $8-10 \mathrm{~m}$ ) alternate with the layers, varying from tens to a few hundreds of meters in thickness and composed of massive or schlieren-banded rocks. The linear banding folds are most distinct in the northern segment of the Akkermanovka fragment, where they have NW strikes and the gentle and medium-size angles of their limb inclination. The total layering is disturbed by the late gabbronorite and pyroxenite veins cutting the banding at low angles. The latest injections were of pegmatoid gabbro. The composition of the gabbro- "pegmatites" correlates with that of the country rocks.

[44] It should be noted that in contrast to the Akkermanovka fragment, the layered rocks of the Kirpichnyi fragment compose a horizon of the mutually intersecting the layered intrusions of the dunite-wehrlite-pyroxenite and gabbronorite-plagiowebsterite composition, their host rocks being the rocks of the dunite-harzburgite complex. This difference in the structure of the layered rock complex in the same ophiolite sequence can be indicative, for the other conditions being equal, of the lateral heterogeneity of the crustal "layer" of the Khabarny ophiolites, for which the "classic" consistent layer of the rocks of the layered complex is replaced along the strike by scattered, cross-cutting intrusions of similar composition, but of different ages [Razumovskiy, $2005]$.

[45] The characteristic feature of the Akkermanovka dike complex is the almost complete absence of its root (transitional) zone. The low-crust gabbroids (gabbronorite) include single cross-cutting diabase dikes and plagiogranite veins, while the bottom part of the dike complex includes merely a few thin screens, composed only of gabbronorite. The zone of the upper magma source, which fed the sheeted dikes, and is represented in the Kirpichnyi fragment by a thick stockwork of gabbro-plagiogranite bodies, is represented by two discon- nected thin amphibole gabbro bodies. A distinctive feature of the sheeted dike complex of the Akkermanovka fragment is that it includes a substantial amount of granitoids which had been intruded almost simultaneously and mainly in local areas, one of the examples being a large granitoid block in the Banka R. Valley.

[46] The discovered specific structure of the sheeted dike complex of the Uzembaev fragment shows a significant similarity with the structural features of the similar rocks studied in the Khabarny ophiolites (Akkermanovka and Kirpichnyi fragments). It should be noted that the petrochemical similarity of the subvolcanic rocks developed in all of the areas discussed had been reported earlier [Tishchenko and Smirnova, 1995; Tishchenko et al., 1983; to name but a few].

[47] It can be assumed with high probability that the Uzembaev fragment of the dike complex is a part of some common, tectonically disintegrated sheeted dike complex, the upper rocks of which had been tectonically moved closer to the layered rocks of the Akkermanovka fragment.

[48] Therefore, the following structural mechanisms can be inferred for the dike complexes of the ophiolite sequence. The early sheeted dikes were intruded into the apoharzburgite serpentinites including pegmatoid gabbroid veins and small bodies. Up to the top of the sheeted dike sequence, serpentinite screens can be found along with gabbroid ones, this proving the discrete distribution of the layered rock bodies in the mantle tectonites. The replacement of the early generations of the dike bodies by the late ones corresponds to the replacement of the medium- to fine-grained gabbroid diabase by pyroxene-porphyry diabase. Characteristic of the sheeted dike complex is the manifestation of acid magmatism, expressed in the presence of size-varying veins and the granitoid matrix of the igneous rock breccias. Most of the granite bodies were intruded after the emplacement of the early-generation gabbro-diabase dikes. The spreading process was characterized by the manifestation of several synchronous and closely timed extension axes, both differing in the direction of the vector of the spreading blocks motion.

[49] The volcanic rock complex of the Akkermanovka fragment of the Khabarny Massif ophiolites is distinguished by the ubiquitous development of the consistent tuff and tuffaceous conglomerate breccias proving insignificant breaks in the volcanic activity. The dikes and volcanic rocks of the Akkermanovka fragment include numerous sites of copper sulfide mineralization. It should be noted that similar mineralization (up to small ore occurrences) is characteristic also of the ophiolite dikes and lavas in the western segment of the allochthon (Kirpichnyi fragment) and a block of sheeted dikes in the Main Ural Fault Zone in the vicinity of the Uzembaevo Settlement.

[50] Contrary to the northern and central parts of the Akkermanovka fragment, where the significant volume of the crustal ophiolite sequence can be reconstructed, in the area south of the Banka $R$. upper reaches, one can speak only of individual tectonic wedges (slabs) and blocks, obviously replaced significantly relative to their initial positions. This seems to be the area which was studied by Shcherbakov [1990] as a melange zone.

[51] On the whole, it should noted that the serpentinite 
melanges of tectonic and sedimentary origin are widespread in the Sakmara allochthone (see Figure 1). These rocks had been described first in detail at the beginning of the 1970s [Kamaletdinov, 1974; Peive et al., 1971; Perfiliev and Ruzhentsev, 1973; Pospelov and Ruzhentsev, 1972; to name but a few] and are being studied at the present time [Kalinina et al., 2003; Razumovskiy, 2004b; Ryazantsev et al., 2005, 2006; to name but a few], (A. V. Ryazantsev et al., in press). At the present time most of the geologists rank the Sakmara-Voznesensk zone as the zone wholly composed of serpentinite melange [Morozov, 2001; to name but a few]. The serpentinite melange of the Sakmara allochthone zone contains, apart from the rocks of the mantle tectonites, and of the layered, dike, and lava complexes, also the fragments of the sedimentary cover of the basin, upper mantle rocks, as well as the rocks of the lower and intermediate crust, known in ophiolite allochthons.

[52] The fragments of the sedimentary rock complexes include mixtite blocks composed of clastic rocks whose fragments represent the rocks of the ophiolite association. These are monomictic gabbro breccias, and also polymictic conglomerate breccias composed of gabbroids, diabase, and granite, or of diabase and basalt or basaltic andesite. The sedimentary conglomerate-type breccias may include individual blocks of igneous rock breccias, characteristic of the root zone of the sheeted dike complex. Also widespread are serpentinite (mostly apohartzburgite) conglomerates, gravelites, and sandstones. The blocks composed both of gabbroid breccias and clastic serpentinites include occasional thin (less than $0.5 \mathrm{~m}$ thick) interlayers of red siltstone in which Early Eifelian conodonts were found [Kalinina et al., 2003; Ryazantsev et al., 2005].

[53] The carbonate-rich clastic ultrabasic rocks could be reworked hydrothermally to ophycalcites which are usually treated as the analogs of the modern hydrothermal fields restricted to the mantle tectonites outcropping at the bottom of the basin. Similar to the clastic rocks mentioned above, ophycalcite plays an important role in the structure of the tectonic sedimentary serpentinite melanges of the Sakmara and Sakmara-Voznesensk zones (A. V. Ryazantsev et al., in press), [Ryazantsev et al., 2005; Voznesenskiy et al., 2003; to name but a few]. The northern and central parts of the Sakmara allochthon show a close association of its ophicalcites with the Early and Middle Devonian siliceous solid and clastic rocks [Ryazantsev et al., 2005]. Restricted to the ophiolitic clastic rocks and cherts of the Sakmara Zone are numerous lenses of rift limestone, which were dated Emsian using their macrofauna and algae [Kondratenko et al., 1996; Tishchenko and Smirnova, 1995]. This suggests that the sedimentary cover of the basin with the oceanic crust, the lower and middle rock sequences of which are represented in the Akkermanovka ophiolite fragment, was composed of siliceous solid and clastic rocks, and sedimentary ophiolitic clastic material and ophicalcite.

[54] The enrichment in large-ion (LIL) elements, the high $\mathrm{Nb}$ content, and other petro-geochemical parameters [Fershtater, 2003, 2004; Fershtater and Bea, 1996; Fershtater et al., 1982], as well as the peridotite crystallization temperature (determined using pyroxene), the pyroxene alumina content, and the chromium content of the spinellids [Zhestkova, 2005] proved the supra-subduction nature of the layered rocks of the ophiolite sequence of the Khabarny Massif. The conditions of the emplacement of the sheeted dikes are comparable, based on the geostructural data available, with marginal sea environments [Kurenkov and Perfiliev, 1984; Razumovskiy and Astrakhantsev, 2005; Savelieva et al., 2005]. The petrogeochemical characteristics of the dike-lava portion of the ophiolite rock sequence, such as, the moderate and low $\mathrm{TiO}_{2}$ contents, the high $\mathrm{Mg}$ content, with the high silica content of the rocks, and their high Sr content, prove their similarity to island-arc igneous rocks [Maegov, 1984; Pushkarev and Khazova, 1991; to name but a few]. In spite of the inferred similarity of the formation conditions of the plutonic peridotite-pyroxene-gabbro and dike-volcanic rock complexes, one should take into account that the rocks of the layered complex are, in many respects, not comagmatic to the dike-lava, spreading part of the rock sequence discussed [Fershtater and Bea, 1996; Fershtater et al., 1982; Perfiliev and Kheraskov, 1980; Semenov, 2000; to name but a few]. At the same time, the insignificant volume of the effusive rocks and the abundance of the ophiolite clasts and ophicalcites, including the sulfide ones, allow one to infer the conditions, similar to the modern zones of "dry" slow spreading in the vicinity of MOR and transform fault intersections. Associated with the rising steps of the latter is the emplacement of reef limestones [Ryazantsev et al., 2005].

[55] It follows from the above that the rocks of the crustal segments of the ophiolite association of the Khabarny Massif, including the ophiolites of the Akkermanovka fragment, might have been formed under the conditions of a supra-subduction marginal sea basin. In this case spreading seems to have developed with a magma budget deficiency [Ryazantsev et al., 2005] and was characterized by the formation of numerous synchronous and close-in-time extension axes, the latter differing in the direction of the spreading block movement. The evolution of the spreading process in time was accompanied by the relative velocity decline and by the active effect of the shear component [Razumovskiy and Astrakhantsev, 2005]. Along with the areas covered by lava flows, mantle tectonites were exposed in the basin floor, also rising to the floor were the fragments of the layered rock and dike complexes. The products of their erosion produced sedimentary ophiolite-clastic rocks. The presence of the ophiolite clasts composed of diabase and plagiogranite suggest the tectonic activity which accompanied the process of slow scattered spreading. Where hydrothermal fields had been restricted to the ultrabasic rocks outcropping in the basin floor, ophicalcites, including ore-bearing ones, were formed. The accessory chrome spinelides of the ultrabasic rocks and the transformed chrome spinelides of the pyrite-pyrrhotite and chalcopyrite-pyrite-pyrrhotite ores of the Ishkino sulfide deposit occur as fragments in the terrigenous rocks of the Ishkino Formation [Dunaev, 2006] which was dated Late Eifelian-Early Givetian, using their conodonts [Artyushkova and Maslov, 1998]. The upper age limit of the process described seems to be the Famenian time, since the sulfides from the cobalt-copper sulfide-bearing ophicalcite of the Dergamysh ore deposit have a Re-Os absolute age of $366 \pm 2$ million years [Gannoun et al., 2003]. The siliceous rock 
cover of this basin continued to accumulate to the end of the Devonian [Ryazantsev et al., 2005].

[56] During the Late Devonian-Early Carboniferous time the rock complexes mentioned above were included into the accretion prism and later were thrust together with the slabs of the Ordovician-Devonian rocks over the edge of the East European Continent [Puchkov, 2000; Ruzhentsev, 1976, 2005; to name but a few]. The root suture of the Sakmara marginal allochthon and the Sakmara-Voznesensk zone (the zone of the Main Ural Fault) existed during the collision time as an overthrust accompanied by left shears [Ivanov, 1998]. It is possible that this whole fragment of the oceanic crust was broken by the above-mentioned left shear faults into individual blocks which now exist as the isolated Khalilov and Khabarny massifs (see Figure 1). It should be noted that the upthrust-overthrust constituent for the South Ural segment of the Main Ural Fault was discussed by many researchers [Saveliev et al., 1998; Seravkin et al., 2001; to name but a few].

[57] The end of the Early Carboniferous time seems to have been the upper age limit of the active movements along the Main Ural Fault zone in the South Ural region. This is proved by the sealing of its suture zone by the Syrostan granitoid massif of the Early Carboniferous age [Morozov, 2001]. Some fragments of this suture experienced faulting during the Early Mesozoic post-collision extension [Ivanov, 1998], yet the Late Triassic-Middle Jurassic coal-bearing rocks of the Orsk-Tanalyk Depression include strictly horizontal quartz sand interbeds which do not show any traces of deformation [Morozov, 2001]. As has been mentioned above, the western limitation of the suture zone of the Main Ural Fault in this area was the East-Uraltau Fault, which operated during its final activity as a normal gravity fault with its down-thrown eastern limb [Abdulin et al., 1977; Khvorov et al., 1971]. This fault detached the Akkermanovka fragment of the crustal ophiolite sequence from the main body of the Khabarny Massif. This fault movement can be dated Cretaceous, because displaced along with the Middle Jurassic terrigenous rocks were the Maastrichtian glauconite sands and argillaceous limestones [Khvorov et al., 1971].

[58] Acknowledgments. The field work was done, in different periods of time, together with E. V. Pushkarev (Institute of Geology and Geophysics of the Ural Department of the Russian Academy), as well as with O. V. Astrakhantsev, A. V. Ryazantsev, and N. B. Kuznetsov (Geological Institute of the Academy), D. S. Shvakov, and D. A. Press (RSGPU), and A. B. Zhestkova (Moscow University). Various aspects of the problems treated in this paper were discussed with E. V. Pushkarev, K. E. Degtyarev, V. L. Zlobin, O. A. Korchagin, G. E. Nekrasov, A.V. Ryazantsev, and G. N. Savelieva (Geological Institute of the Academy). I thank all of them sincerely. This work was supported by the Russian Foundation for Basic Research, Project no. 03-05-64142, and by the Earth Science Department of the Academy, Programs: "The deep structure of the Earth: Geodynamics, magmatism, and interaction of its geospheres" and "The geodynamic evolution of the lithosphere of the Central Asia foldbelt: from the paleoocean to the continent".

\section{References}

Abdulin, A. A., A. V. Avdeev, and N. S. Seitov (1977), The Tectonics of the Sakmara and Or-Ilek Mugodzhar Zones, 241 pp., Nauka, Alma-Ata.

Artyushkova, O. V., and V. A. Maslov (1998), The Paleontological Substantiation of the Stratigraphic Subdivision of the pre-Famennian Volcanic Rocks in the Upper Ural and Magnitogorsk Regions, 156 pp., Institute of Geology of the Ural Science Center, Russian Academy, Ufa.

Balykin, P. A., E. G. Konnikov, and A. P. Krivenko (1991), The Petrology of the Post-Hartzburgite Intrusions of the Kempirsai-Khabarny Ophiolite Association (South Ural), 160 pp., Ural Division of the Academy, Sverdlovsk.

Biryuzova, A. P., and E. V. Pushkarev (2004), The highly metamorphic sedimentary rocks surrounding and composing the East Khabarny ultramafic-mafic rock complex (South Ural), in The Geology and Metallogeny of Ultramafic-Mafic and Granitoid Intrusive Rock Associations in Folded Areas, Proc. International Conference (A. N. Zavaritskiy Xth Readings), p. 99, Institute of Geology and Geophysics, Ural Division, Russian Academy of Science, Ekaterinburg.

Borisenok, D. V., and A. V. Ryazantsev (2005), Lower Paleozoic volcanic rocks in the contact zone of the Sakmara and the Sakmara-Voznesensk zones, in Essays of Regional Tectonics, vol. 1, South Ural, Proc. Geol. Institute, Russian Academy, Iss. 561, p. 135, Nauka, Moscow.

Borisenok, D. V., A. V. Ryazantsev, S. V. Dubinina, and E. V. Raznitsyna (2002), Ordovician and Devonian Rocks at the Southern Termination of the Uraltau Range: Modern Problems of the Geology, 157 pp., Nauchnyi Mir, Moscow.

Coleman, R. G. (1971), Plate tectonic emplacement of upper mantle peridotites along continental edges, J. Geophys, Res., 76,1212 .

Dewey, J. F., and J. M. Bird (1971), Origin and emplacement of the ophiolite suite: Appalachian ophiolites in Newfoundland, J. Geophys. Res., 76, 3179.

Dunaev, A. Yu. (2006), The conditions of the formation and the time of the erosion of the ultramafic rocks and pyrite ores of the Ishkino deposit, in Ophiolites: Geology, Petrology, Metallogeny, and Geodynamics, Proc. Internat. Sci. Conference (XII readings in memory of A. N. Zavaritskiy), p. 268, Institute of Geology and Geophysics, Ural Division of the Academy, Ekaterinburg.

Fershtater, G. B. (2003), The supra-subduction intrusive magmatism of the Ural region, Geol. Geofiz, 44(12), 1349.

Fershtater, G. B. (2004), The nature of the Silurian-Early Devonian mafic-ultramafic intrusions, associated with the South Ural ophiolites, Lithosphere, 4, 3.

Fershtater, G. B., and F. Bea (1996), The geochemical types of the Ural ophiolites, Geochemistry, 33(3), 195.

Fershtater, G. B., F. Bea, N. S. Borodina, and P. Montero (1998), The lateral zoning, evolution, and geodynamic interpretation of the Ural igneous rocks in the light of new petrologic and geochemical data, Petrology, 6(5), 451.

Fershtater, G. B., N. S. Borodina, E. V. Pushkarev, and V. A. Chashukhina (1982), The Gabbro and Granitoids Associated with the Ultrabasic Rocks of the Kempirsai and Khabarny Massifs in the South Ural Region, 74 pp., Ural Research Center of the Academy preprint, Sverdlovsk.

Gannoun, A., S. Tessalina, and B. Bourdon (2003), Re-Os isotopic constraints on the genesis and evolution of the Dergamish and Ivanovka $\mathrm{Cu}(\mathrm{Co}, \mathrm{Au})$ massive sulfide deposits, South Urals, Russia, Chem. Geol., 196, 193, doi:10.1016/S00092541(02)00413-8.

Gottman, I. A. (1997), The composition of chrome spinellids from the peridotite-hornblendite breccias of the Khabarny Massif (South Ural), in The Ural Summer Mineralogical School-97, Proc. All-Russian Science Conference of Students, Post-Graduate Students, Research Workers, and University Teachers, p. 44, Uralian Association of Geologists and 
Geophysicists and All-Russian Society of Mineralogist, Ekateriburg.

Ivanov, K. S. (1988), The age of the Ural Kempirsai-Khabarny ophiolite association, in Formational Subdivision, Genesis, and Metallogeny of Ultrabasic Rocks, p. 65, Institute of Geology and Geophysics, Ural Division of the Academy, Sverdlovsk.

Ivanov, K. S. (1998), The Main features of the geological history (1.6-0.2 billion years) and structure of the Ural Mountain Range, Doctor Dissertation Presented as a Scientific Paper, p. 252, Ural Division of the Academy, Ekateriburg.

Ivanov, K. S., V. N. Puchkov, and I. A. Pelevin (1984), New data for the geology of the rocks surrounding the Khabarny gabbro-ultrabasic massif (South Ural), Yearbook of the Zavaritskiy Institute of Geology and Geophysics, 1983, p. 27, Ural Division of the Academy, Sverdlovsk.

Kalinina, E. A., A. V. Ryazantsev, and S. V. Dubinina (2003) The structural position, lithology, and age of the ophiolite clastic mixtites of the South Ural Sakmara zone, in Modern Problems of Geology: Proc. of the Conference of Young Geologists: 3d Yanshin Readings, p. 18, Institute of Lithosphere, Russian Academy, International Tectonic Committee, "Integration" Federal Center, Nauchnyi Mir, Moscow

Kamaletdinov, M. A. (1974), The Nappes of the Ural, 232 pp., Nauka, Moscow.

Kamaletdinov, M. A., and T. T. Kazantseva (1970), The specific structure of the South Ural nappes and overthrust sheets, Bull. Moscow Researchers of Nature, Geol. Series, 45(4), 60.

Kheraskov, N. P. (1971), The Ebetin overthrust sheet in the South Ural region, Geotectonics, 5(4), 26.

Khvorov, V. I., V. I. Maegov, V. A. Kolotilov, and V.M. Sychev (1971), The Geological Structure and Mineral Deposits of the Khabarny Ultrabasic Rock Massif, A Report of the Guberlya Prospecting and Revision Party for 1967-1971 period of time, PGO, Orenburg.

Kondratenko, V. F., N. T. Vidyukov, A. A. Burmistrov, and R. A. Sinyak (1996), The Geological Structure and Mineral Resources in the Northern Part of the Mednogorsk Ore-Bearing Area, Report of the Sakmara geological party on the repeated study on the scale of 1:50 000 and on the general search operations in the areas of the M-40-8-V, M-40-19-B, and M-40-20-A map sheets of the Mednogorsk ore-bearing area in 1989-1995, "Orenburggeology", Nezhinka Village.

Kopteva, V. V., A. S. Perfiliev, and N. N. Kheraskov (1979), The diabase complexes of the Khabarny ophiolite association in the South Ural, Dokl. Akad. Nauk SSSR, 248(4), 927.

Krasnobaev, A. A., F. Bea, G. B. Fershtater, and P. Montero (2004), The age, morphology, and geochemistry of zircons from the basic rocks of the Ural (ophiolites and platinumbearing belt) and the acid rocks associated with them, in The Geology and Metallogeny of the Ultramafic-Mafic and Granitoid Intrusive Rocks of the Folded Regions, Proc. International Conference (10th Zavaritskiy Readings), p. 211 , Institute of Geology and Geochemistry, Ural Division of the Academy, Ekaterinburg.

Kurenkov, S. A., and A. S. Perfiliev (1984), Dike complexes and their tectonic interpretation, Geotectonics, 18(5), 3.

Maegov, V. I. (1977), The Petrology of the gabbroids of the Khabarny gabbro-ultrabasic-rock massif (South Ural), A dissertation presented for a candidate degree, Institute of Geology and Geophysics, Ural Division of the Academy, Sverdlovsk.

Maegov, V. I. (1984), The geochemistry of the Khabarny Massif gabbroids and of the rocks associated with them, Yearbook of the Zavaritskiy Institute of Geology and Geophysics, 1983, p. 86, Ural Division of the Academy, Sverdlovsk.

Moores, E. M., and F. J. Vine (1971), Troodos Massif, Cyprus and other ophiolites as oceanic crust: Evaluation and implications, Roy. Soc. London Philos. Trans., A 268, 443.

Morozov, A. F., (Ed.) (2001), The Deep Structure and Geodynamics of the South Ural (Uralseis Project), 286 pp., GERS, Tver.

Paneyakh, N. A. (1989), Spinelides of the banded ophiolite rock complexes, Mineralogical Journal, 11(2), 3.
Peive, A. V. (1969), Oceanic crust of the geological past, Geotectonics, 3(4), 5.

Peive, A. V., N. A. Shtreis, and A. S. Perfiliev (1971), The structural position of the ultrabasic rocks at the western slope of the South Ural, in The Problems of Theoretical and Regional Tectonics, p. 9, Nauka, Moscow.

Peive, A., S. Ivanov, A. Perfiliev, and V. Puchkov, (Eds), (1977), Tectonics of the Ural Region: Explanatory Notes for the Tectonic map of the Ural Region, Scale 1:1,000 000, 120 pp., Nauka, Moscow.

Perfiliev, A. S. (1979), The formation of the Earth Crust in the Ural Eugeosynckine, in Proc. of the Geological Institute of the USSR Academy, Iss. 328, p. 188, Nauka, Moscow.

Perfiliev, A. S., and S. V. Ruzhentsev (1973), The structural position of the gabbro-ultrabasic rock complexes in fold belts, Geotectonics, 7(3), 14

Perfiliev, A. S., and N. N. Kheraskov (1980), The diabase complexes and the problem of the tectonic layering of the oceanic crust, in Tectonic Layering of the Lithosphere, Proc. of the Geological Institute of the USSR Academy, Iss. 343, p. 64, Nauka, Moscow.

Pospelov, I. I., and S. V. Ruzhentsev (1972), The "ophiolite complex" of the central part of the South Ural Sakmara Zone, Dokl. Akad. Nauk SSSR, 203(1), 179.

Puchkov, V. N. (2000), South and Middle Ural Paleogeodynamics, 146 pp., Dauriya, Ufa.

Pushkarev, E. V. (1998), The Depleted Lherzolites of the Khabarny Massif in the South Ural, Yearbook of the A. N. Zavaritskiy Institute of Geology and Geophysics, p. 109, Ural Division of the Academy, Ekaterinburg.

Pushkarev, E. V., and N. A. Khazova (1991), The complex of the sheeted dikes of the Khabarny Massif: Was it produced by the spreading of an oceanic ridge or of an island arc?, Yearbook of the A. N. Zavaritskiy, p. 40, Institute of Geology and Geophysics, Uralian Division of the Academy, Sverdlovsk.

Pushkarev, E. V., and B. A. Kaleganov (1993), The K-Ar dating of the igneous rock complexes of the Khabarny gabbroultrabasic rock massif (South Ural), Dokl. Ros. Akad. Nauk, 328(2), 241.

Pushkarev, E. V., and G. B. Fershtater (1995), The mineralpetrochemical discreteness of rocks and the problem of the origin of the primary magmas of the dunite-clinopyroxenegabbro complexes, in The Actual Problems of Magmatic Geology, Petrology, and Ore Formation, p. 100, Uralgeolcom, Ekaterinburg.

Pushkarev, E. V., G. B. Fershtater, and F. Bea (1996), The REE geochemistry as the criterion of the belonging of the East Khabarny complex to platinum-bearing ultrabasic rock and gabbro associations, The A. N. Zavaritskiy Year Book, 1995, p. 90, Institute of Geology and Geophysics of the Ural Subdivision of the Academy, Ekaterinburg.

Razumovskiy, A. A. (2004a), The geological structure of the Khabarny allochthon: The western fragment between the Guberlya and Chebakla Rivers, in The Geology and Metallogeny of Ultramafic-Mafic and Granitoid Intrusive Rock Associations in Folded Areas, Proc. International Scientific Conference (Xth A. N. Zavaritskiy Readings), p. 148, Institute of Geology and Geophysics, Ural Division of the Academy, Ekaterinburg.

Razumovskiy, A. A. (2004b), The geological structure of the Khabarny allochthon: The western fragment at the Ural River, in The Geology and Metallogeny of Ultramafic-Mafic and Granitoid Intrusive Rock Associations in Folded Areas, Proc. International Scientific Conference (Xth A. N. Zavaritskiy Readings), p. 152, Institute of Geology and Geophysics, Ural Division of the Academy, Ekaterinburg.

Razumovskiy, A. A. (2005), The layered rock complex of the ophiolite association in the Khabarny Massif (South Ural), in The Structure of the Lithosphere and Geodynamics, Proc. of the XXI All-Russia conference of young geoscientists, p. 61, Institute of the Earth Crust, Siberian Division of the Academy, Irkutsk.

Razumovskiy, A. A. (2006), The complex of sheeted dikes in the melange zone of the Main Ural Fault (the north of 
the Khabarny structural saddle, South Ural), in Ophiolites: Geology, Petrology, Metallogeny, and Geodynamics, Proc. of the International Conference, XII readings in memory of A. N. Zavaritskiy, p. 144, Institute of Geology and Geophysics, Ural Subdivision of the Academy, Ekaterinburg.

Razumovskiy, A. A., and O. V. Astrakhantsev (2005), The structural features of the sheeted dike complex of the Khabarny Massif ophiolite association, in Essays on Regional Tectonics, vol. 1, South Ural, Proc. of the Geological Institute, Russian Academy, Iss. 561, p. 179, Nauka, Moscow.

Ruzhentsev, S. V. (1976), The marginal ophiolite allochthons: Tectonic nature and structural positions, in Proc. Geol. Institute, USSR Academy, Iss. 283, p. 172, Nauka, Moscow.

Ruzhentsev, S. V. (2005), The facies sheets in the structure of the western slope of the South Ural, in Essays of Regional Tectonics, vol. 1, South Ural, Proc. Geol. Institute, Russian Academy, Iss. 561, p. 56, Nauka, Moscow.

Ruzhentsev, S. V., and G. N. Savelieva (2003), The ophiolites in the collision structure, Dokl. Ros. Akad. Nauk, 391(5), 663.

Ryazantsev, A. V., D. V. Borisenok, and S. V. Dubinina (2005), The general structure of the South Ural Sakmara Zone in the area of the Mednogorsk pyrites deposits, in Essays on the Regional Tectonics, vol. 1, The South Urals, Proc. of the Geological Institute, Russian Academy, Iss. 561, p. 84, Nauka, Moscow.

Ryazantsev, A. V., A. A. Razumovskiy, and N. B. Kuznetsov (2006), Metamorphic rocks and sheeted dikes in the South Ural serpentinite melange, in Ophiolites: Geology, Petrology, Metallogeny, and Geodynamics, Proc. Intern. Scientific Conference (XII Readings in the memory of A.N. Zavaritskiy), p. 157, Institute of Geology and Geophysics, Ural Division of the Academy, Ekaterinburg.

Saveliev, A. A., O. V. Astrakhantsev, and A. L. Knipper (1998), The structure and deformation phases of the northern termination of the Magnitogorsk Zone of the Ural Region, Geotectonics, 32(3), 38.

Savelieva, G. N., K. E. Degtyarev, S. V. Ruzhentsev, and A. V. Ryazantsev (2005), The geodynamic environment of the South Ural ophiolite formation, in The Tectonics of the Earth Crust and Mantle: Tectonic Control of Useful Mineral Accumulation, Proc. XXXVIII Tectonic Conference, vol. 2, p. 165, GEOS, Moscow.

Semenov, I. V. (2000), The Paleooceanic Spreading Volcanism of the Ural Region and the Reconstruction of the Size of the Ural Paleozoic Ocean, 368 pp., Ural Research Center of the Academy, Ekaterinburg.

Semenov, I. V., L. I. Kolenko, and A. A. Shtenke (1980), Rare earth elements in the basalts of the volcanic rock sequences of the Ural eugeosyncline, in Admixed Elements in Minerals and Rocks, p. 36, Ural Research Center of the Academy, Sverdlovsk. Seravkin, I. B., S. E. Znamenskiy, and A. M. Kosarev (2001),
Fault Tectonics and Ore Deposits in the Bashkirian East Ural Region, 318 pp., Poligraph. Company, Ufa.

Shcherbakov, S. A. (1990), The plastic deformations of the ultrabasic rocks in the Ural Region, in Proc. Geol. Institute of the USSR Academy, Iss. 450, p. 120, Nauka, Moscow.

Sobolev, I. D., (Ed.) (1979), The Geological Map of the Ural Region, scale 1:500 000, 220 pp., Ministry of Geology, Moscow. Tishchenko, V. T., and I. A. Smirnova (1995), Preparation of geological maps, scale 1:200 000, for the eastern part of the Orenburg Region, Report of the South Ural Party for the 19891995 period of time, "Orenburggeology", Nezhinka Village.

Tishchenko, V. T., S. K. Irkatanov, and A. Z. Plotnikov (1983), Report on the Deep Geological Mapping, Scale 1:50 000, of the territory covered by the map sheets of M-40-9-B (c, d); M40-21-A, B; M-40-33-A, B (a, b) in 1978-1983, Khalilov area, PGO, Orenburg.

Varlakov, A. S. (1966), The petrochemistry of ultrabasic rocks in the Orenburg area, in The Geology and Mineral Resources of the Ural Region, iss. 48, p. 42, Proc. Mining Institute, Sverdlovsk.

Varlakov, A. S. (1978), Petrography, Petrochemistry, and Geochemistry of Ultrabasic Rocks in the Orenburg Ural, 240 pp., Nauka, Moscow.

Varlakov, A. S. (1996), The Dunite-Wehrlite-Clinopyroxenite Complex of Ophiolites and Its Origin, 178 pp., Institute of Geology and Geophysics, Ural Division of the Academy, Ekaterinburg.

Varlakov, A. S., E. P. Tsaritsyn, and S. I. Matveev (1967), Field survey operations at the Khabarny Massif, scale 1:10 000, Intermediate Report, Institute of Geology and Geophysics, Ural Division of the Academy, Sverdlovsk.

Varlakov, A. S., and S. I. Matveev (1978), The Akkermanovka dunite-clinopyroxene-gabbro intrusion of the Khabarny ultrabasic rock massif, in The Magmatism and Metamorphism of the Ultrabasic and Alkalic Rocks of the Orenburg Ural, p. 3, The Unitary Scientific Center, Sverdlovsk.

Voznesenskiy, A. I., A. L. Knipper, and V. A. Koroteev (2003), The Lower Devonian redeposited serpentinite clastic weathering crust (the Sakmara-Voznesensk Zone of the South Ural), Lithology and Mineral Deposits, 3, 227.

Zhestkova, A. V. (2005), The geodynamic environment of the formation of the dunite-clinopyroxenite-gabbro complex in the western part of the Khabarny Massif, in Tectonics of the Crust and Mantle and the Tectonic Distribution of Mineral Deposits, Proc. of the XXXVIII Tectonic Conference, vol. 1, p. 230, GEOS, Moscow.

A. A. Razumovskiy, Geological Institute of the Russian Academy of Sciences, 7 Pyzhevskii Lane, Moscow, 119017 Russia (e-mail: razumovski@ginras.ru) 